University of Miami Law School University of Miami School of Law Institutional Repository

Articles

Faculty and Deans

1992

\title{
Heat of Passion and Wife Killing: Men Who Batter/Men Who Kill
}

Donna K. Coker

University of Miami School of Law, dcoker@law.miami.edu

Follow this and additional works at: https://repository.law.miami.edu/fac_articles

Part of the Law and Gender Commons, and the Law and Society Commons

\section{Recommended Citation}

Donna K. Coker, Heat of Passion and Wife Killing: Men Who Batter/Men Who Kill, 2 S. Cal. Rev. L. \& Women's Stud. 71 (1992).

This Article is brought to you for free and open access by the Faculty and Deans at University of Miami School of Law Institutional Repository. It has been accepted for inclusion in Articles by an authorized administrator of University of Miami School of Law Institutional Repository. For more information, please contact library@law.miami.edu. 


\title{
HEAT OF PASSION AND WIFE KILLING: MEN WHO BATTER/ MEN WHO KILL
}

\author{
DONNA K. COKER*
}

"[Adultery is the] archetypical illustration of adequate provocation."

\section{INTRODUCTION}

Men who beat their wives or lovers ${ }^{2}$ frequently allege that the woman's infidelity or her desire to be unfaithful provoked the beat-

* Litigation Associate, Heller, Ehrman, White \& McAuliffe. B.A. 1978, Harding University; M.S.W. 1982, University of Arkansas at Little Rock; J.D. 1991, Stanford Law School. Martha Mahoney provided invaluable insight and support for the development of this paper as did Robert Weisberg, Carol Sanger, Lynne Henderson, and Blanca Silvestrini. Thanks to Debbie Jackson and Juanita Briscoe for their able typing assistance and to the partners of Heller for their support of this project. This article is dedicated to my husband, Tom Dukowitz, who made this article possible by his willingness to pick up my share of the childcare and housework. I also owe a debt of gratitude to the women of Maluhia ' $O$ Wahine whose courage, as Suzanne Pharr describes it, to "walk right into the unknown," has shaped my thinking about battering, and especially to my dear friend Kristine Woodall, whose common sense and fierce partisanship with women is ever a source of strength.

1. People v. Thompkins, 240 Cal. Rptr. 516, 518-19 (Ct. App. 1987) ("At least as early as Manning's Case (1793) 83 Eng. Rep. 112, an archetypical illustration of adequate provocation to invoke the common law heat-of-passion theory for voluntary manslaughter has been the defendant's discovery of his wife in bed with another man.").

2. For the sake of brevity, I will sometimes use the terms wives and lovers to also include former wives and lovers. The distinction, however, is an important one. More women are killed when they separate, or attempt to separate, from an abusive man than when they are "with" him. Norman J. Brisson, Battering Husbands: A Survey of Abusive Men, 6 Victimology 338 (1983) (finding that over half of male domestic homicide perpetrators studied were separated from the victim at the time of the homicide; only $9.1 \%$ of the female perpetrators were separated at the time of the killing). See generally Martha R. Mahoney, Legal Images of Battered Women: Redefining the Issue of Separation, 90 MicH. L. REv. 1, 49-53 (1991) (suggesting that the term "separation assault" be used to identify those attacks which are in response to a woman's attempt to separate or are in retaliation for separation). Furthermore, the term "wife-killing," unless stated otherwise, is meant to include the homicide of female intimates, or former intimates, whether or not they were ever legally married to the killer. This article does not explore the differences, if indeed there are any, between murders of wives and murders of lovers who are not married to the offender. See Zimring et al., Intimate Violence: A Study of Intersexual Homicide in Chicago, 50 U. CHr. L. REv. 910, 918 (1983) (finding more frequent homicides involving "girlfriends" and "boyfriends" than between married couples). This article will focus on heterosexual battering. This is in no way meant to diminish the significance of battering in gay and lesbian relationships, however. See generally NAMING THE 
ing. ${ }^{3}$ Research regarding men who kill their wives suggests that they are similarly motivated by sexual jealousy. ${ }^{4}$ Although jealousy is not the only motivation given by men who beat or kill their wives, claiming adultery as provocation may mean the difference between a voluntary manslaughter conviction and a murder conviction. The voluntary manslaughter law of practically every jurisdiction will recognize provocation induced by the sight of a wife's adultery as a motivation to kill. ${ }^{5}$ In fact, English and American jurists and legal scholars repeatedly refer to adultery as the paradigm example of provocation adequate enough to mitigate what would otherwise be murder to a voluntary manslaughter conviction. ${ }^{6}$

VIOLENCE: SPEAKING OUT ABout LESBIAN BATTERING (Kerry Lobel ed., 1986) (collection of essays and materials regarding battering in lesbian relationships); DAvid ISLAND \& PATRICK Letellier, Men Who BeAt THE Men Who LOVE Them: Battered Gay Men and Domestic VIOLENCE (1991) (discussing battering in gay male relationships).

3. See Laura L. Crites, Wife Abuse: The Judicial Record, in Women, THE CouRTS, AND EQUALITY 38, 50 (Laura L. Crites \& Winifred L. Hepperle eds., 1987) ("An unfaithful, promiscuous wife is perhaps the most frequently offered justification by the abusing husband for his violence... It should be noted that extreme irrational jealousy is one of the most common characteristics of abusing husbands."); R. Emerson Dobash \& Russell P. Dobash, The Nature and Antecedents of Violent Events, 24 BRIT. J. CRIMINOLOGY 269, 274 (1984) ("[S]ources of conflict [in battering relationships studied] centered on three main issues-possessiveness and jealousy, demands concerning domestic labour and service, and money."); James Ptacek, Why Do Men Batter Their Wives?, in FeMinIST PERSPEctrves ON WIFE ABUSE 133, 148 (Kersti Yllö \& Michele Bograd eds., 1988) (batterer's charges of infidelity are marked by themes of self-righteousness). Maria Roy, Probing a Cross-Section of Battered Women: A Current Survey of 150 Cases, in BATTERed WoMEN: A Psychsociological Study of Domestic Violence 41-42 (Maria Roy ed., 1977) (finding jealousy to be second only to arguments over money as precedents to violence).

4. Pathological jealousy is "a significant indicator of the potential for homicide." David Adams, Identifying the Assaultive Husband in Court: You Be the Judge, RESPONSE TO VICTIMIZATION WOMEN \& ChILDREN, 1990, at 13, 14. See generally Brisson, supra note 2, at 341 (from 41\% to $66 \%$ of wife-killers studied said jealousy proceeded the violence). Anecdotal evidence also suggests that jealousy is frequently given as an explanation for domestic homicides committed by men. See generally Matt Lait \& Davan Maharaj, Terror in Lido Trailer Park, L.A. TIMEs, Feb. 6, 1990, at B1 (when describing a man's murder of his ex-wife, acquaintances noted that he was a "jealous husband": "He would always seem to think that she was fooling around with someone else and he wouldn't let her out of his sight. ...").

5. "It is the law practically everywhere that a husband who discovers his wife in the act of committing adultery is reasonably provoked, so that when, in his passion, he intentionally kills either his wife or her lover (or both), his crime is voluntary manslaughter rather than murder." WAYNE R. LAFAVE \& AUSTIN W. ScotT, JR., Criminal LAW 656 (2d ed. 1986). Jurisdictions differ regarding the effect of mere knowledge of adultery as opposed to actually witnessing an adulterous act. Id. at 657. The "modern" rule no longer depends on discrete categories of provocation as a matter of law, but rather uses a reasonable person standard, leaving the question of adequacy to the jury. Rolin M. Perkins \& Ronald N. Boyce, Criminal LAw 86-87 (3d ed. 1982).

6. See, e.g., A. J. Ashworth, The Doctrine of Provocation, 35 CAMBRIDGE L.J. 292, 294 (1976) (describing the provocation of a man finding his wife committing adultery as provocation "of the highest degree"). See also People v. Thompkins, $240 \mathrm{Cal}$. Rptr. at 518 (the "archetypical illustration of adequate provocation" is a wife's adultery). At least one author notes that of all the traditional 
The elevation of adultery to the status of the paradigm example of provocation is notable for several reasons. Adultery is an anomaly in the common law doctrinal world of provoking events, and it is the only major traditional category of "adequate provocation" that does not involve an actual or threatened physical assault. ${ }^{7}$ Even though adulteryrelated killings comprise the singular area of homicide law that has historically distinguished a wife-killing from all other killings, these killings are seldom recognized as belonging to the universe of "domestic violence" killings. Wife-killing is therefore excluded from the modern analysis afforded wife abuse. ${ }^{8}$

Recent years have seen an explosion of interest and research in both the social sciences and law with regard to the violence of men against their present or former wives or lovers. Legal scholarship has focused primarily on the challenges involved in the representation of battered women - in temporary restraining order hearings, ${ }^{9}$ child custody fights, ${ }^{10}$

categories of adequate provocation, "adultery appears to have best resisted the changes brought about by time." Laurie J. Taylor, Comment, Provoked Reason in Men and Women: Heat-of-Passion Manslaughter and Imperfect Self-Defense, 33 UCLA L. REv. 1679, 1688 n.55 (1986).

7. SaNford H. Kadish \& Stephen J. Schulhofer, Criminal Law AND ITs Processes: CASes and Materials 441-42 (5th ed. 1989) ("The traditional common law view . . . did not permit a jury to return a verdict of manslaughter in any and all situations which the jury might find reasonably provocative. Only certain narrowly defined provoking circumstances, cases of "legally sufficient' provocation, could justify a manslaughter verdict. The principal 'legally sufficient' provocation was an actual physical battery. There were a few others, such as personally witnessing a wife having sexual relations with another.").

The justification of this restrictive view was stated as follows in State v. Starr, 38 Mo. 270, 277 (1886):

To have the effect to reduce the guilt of killing to the lower grade, the provocation must consist of personal violence. This rule is well established. ... There must be an assault upon the person, as where the provocation was by pulling the nose, purposely jostling the slayer aside in the highway, or other direct and actual battery.

8. Currently, there is some limited use of expert testimony in prosecutions of men for assaulting their female partners. See, e.g., Daniel Jay Sonkin \& William Fazio, Domestic Violence Expert Testimony in the Prosecution of Male Batterers, in Domestic VIOLENCE on TRIAL: PsychologiCal and Legal Dimensions of Family Violence 218 (Daniel Jay Sonkin ed., 1987). That testimony has generally been in the form of "battered women's syndrome" testimony, attempting to demonstrate that the victim fits the characteristics of a "battered woman," rather than testimony regarding the characteristics of abusive men.

9. See, e.g., Lauren Robel, The Protective Order Project (unpublished manuscript presented at Law \& Society Conference, Berkeley, CA) 1990 (on file with author) (arguing that emphasis on arrest fails to recognize the benefits in terms of increased negotiating power offered to women through the restraining order process).

10. See Laura Crites \& Donna Coker, What Therapists See That Judges May Miss: A Unique Guide to Custody Decisions When Spouse Abuse is Charged, JuDGES' J. (Spring 1988), at 8; Myra Sun \& Elizabeth Thomas, Custody Litigation on Behalf of Battered Women, 21 Clearinghouse ReV. 563 (1987); Lenore E. A. Walker \& Glenace E. Edwall, Domestic Violence and Determination of Visitation and Custody in Divorce, in DoMestic VIolence on Trial: Psychological aND LEGAL DimenSIONS OF FAMILY VIOLENCE, supra note 8, at 127. 
and, most notably, in the area of criminal defense of women who kill their abusive partner. ${ }^{11}$ Expert testimony regarding "battered woman's syndrome" is now admissible in most states when a woman is charged with the murder of her current or former abusive partner. ${ }^{12}$ When abusive men are prosecuted for assault, many jurisdictions have special domestic violence units or programs that employ a range of strategies from diversionary programs to mandatory jail time. ${ }^{13}$ The judicial system's heightened awareness of and response to wife abuse has led to a better understanding of the motivations of the abuser and the circumstances of the abused woman's existence. Perhaps the two most important insights that have arisen from this activity are the recognition that wife-abuse is purposeful-and not primarily expressive-behavior, ${ }^{14}$ and that battered women are neither masochists nor provocateurs. Men who are identified as abusers are therefore more likely to be held accountable for their violence today than they were twenty years ago.

11. See, e.g., Elizabeth Bochnak, Women's Self-Deffense Cases: Theory and Practice (1981); Charles Patrick Ewing, Battered Women Who KILl: Psychological SelfDefense As Legal Justification (1987); SARa LeE JohanN \& Frank OSANKa, RepresentING . . . BATTERed WoMen Who KILl (1989); Julie Blackman, Potential Uses for Expert Testimony: Ideas Toward the Representation of Battered Women Who Kill, 9 WOMEN's RTS. L. REP. 227 (1986); Holly Maguigan, Battered Women and Self Defense: Myths and Misconceptions in Current Reform Proposals, 140 U. PA. L. REv. 379 (1991); Sue Osthoff, Making A Difference: Adrocating Effectively for Women Who Kill (National Clearinghouse for the Defense of Battered Women, Philadelphia, PA), 1992; Elizabeth M. Schneider, Describing and Changing: Women's Self-Defense Work and the Problem of Expert Testimony on Battering, 9 WOMEN's RTS. L. REP. 195 (1986) [hereinafter Schneider, Describing and Changing]; Elizabeth M. Schneider, Equal Rights to Trial for Women: Sex Bias in the Law of Self-Defense, 15 HARV. C.R.-C.L. L. REv. 623 (1980) [hereinafter Schneider, Equal Rights]; Elizabeth M. Schneider \& Susan D. Jordan, Representation of Women Who Defend Themselves in Response to Physical or Sexual Abuse, 4 WOMEN's RTS. L. REP. 149 (1978).

12. See Maguigan, supra note 11, at 464-67. Maguigan provides an exhaustive look at the status of expert testimony regarding "battered women's syndrome" in all 50 states, reporting 44 states that admit the testimony and 6 for which there was no information.

13. See, e.g., Laura Crites, A Judicial Guide to Understanding Wife Abuse, Judges' J. (Summer 1985), at 4 (describing the program in Honolulu); Ellen Pence \& Melanie Shepard, Integrating Feminist Theory and Practice: The Challenge of the Battered Women's Movement, in FEMINIST PERSPECTIVES ON WIFE ABUSE, supra note 3, at 282 (describing the work of the Domestic Abuse Intervention Project in Duluth, Minnesota); David Adams, Treatment Models of Men Who Batter: A Profeminist Analysis, in Feminist Perspectives on WiFE ABUSE, supra note 3, at 195-96 (referring to court mandated programs for batterers in Minneapolis, Duluth, Seattle, San Francisco, and Atlanta as being instrumental in bringing about pro-arrest policies).

14. "Specialists in the treatment of male batterers have observed that men are violent as a result of their need to control their partner and not as a result of lack of control." Sonkin \& Fazio, supra note 8, at 225. "We would argue that the majority of men who use violence against their wives usually enter verbal confrontations with the intentions of punishing, regulating and controlling their wives through various means including the use of physical force." Dobash \& Dobash, supra note 3, at 286. 
In light of the intense social science and legal activity in the area of domestic violence generally, it is remarkable that this information is frequently absent from the legal analysis when a man's beatings escalate to murder. ${ }^{15}$ Nowhere is this lack more apparent or ironic than in the area of homicide law that has historically distinguished a domestic violence killing from all others: the heat-of-passion killing provoked by discovery of a wife's adultery. ${ }^{16}$

In this article I will apply the growing body of social science data and feminist theory regarding domestic violence to reexamine heat-ofpassion/adultery law. The article is organized around two central points. First, law implies a dubious distinction between men who premeditate the murder of wives and lovers, and "innocent"17 men who catch their wives in bed with someone. This distinction does not accurately describe husband-to-wife homicides. Second, there is a remarkable similarity between the social understandings that underlie important elements of voluntary manslaughter's heat-of-passion doctrine and the excuses and justifications that abusive men give to explain their violence. The primary excuse abusive men give for their violence is that they were "out of control," a claim which is frequently linked with an explicit or implicit charge that it was the victim's provocation that made them lose control. The primary justifications for the violence are that she deserved it due to her improper conduct or, more subtlely, that the man was acting in (emotional) self-defense. Both of these excuses and justifications significantly mirror the understanding of violence that informs voluntary manslaughter/heat-of-passion law.

15. The lack of scholarly attention to legal doctrine regarding adultery-related killings mirrors the general lack of research regarding gender and criminology. See Judith Allen, Men, Crime and Criminology: Recasting the Questions, 17 INT'L J. Soc. L. 19 (1989) ("Feminist criminologists . . identify failure to theorize the basic sex specificities of criminalities as the greatest intellectual faw in 20th century criminology.").

16. On the other hand, the application of voluntary manslaughter doctrine to women who kill husbands or lovers is ably examined by Laurie J. Taylor. Taylor, supra note 6 .

17. By "innocent" I do not mean that these men are necessarily found innocent, but rather that they do not have the "depraved heart" which, in common law, denotes first degree murder. See, e.g., Maher v. People, 10 Mich. 212 (1862).

But if the act of killing, though intentional, be committed under the influence of passion or in heat of blood, produced by an adequate or reasonable provocation, and before a reasonable time has elapsed for the blood to cool and reason to resume its habitual control, and is the result of the temporary excitement, by which the control of reason was disturbed, rather than of any wickedness of heart ar cruelty or recklessness of disposition; then the law, out of indulgence to the frailty of human nature, or rather, in recognition of the laws upon which human nature is constituted, very properly regards the offense as of a less heinous character than murder, and gives it the designation of manslaughter.

Id. at 218-19 (emphasis added). 
This congruence between how abusive men perceive their violence and the legal doctrine of voluntary manslaughter perpetuates two major misconceptions about the nature of wife-killing. The first misconception follows from the belief that violence in response to a wife's provocationin this context, the wife's adulterous conduct-is an uncontrollable response, which in turn reinforces the belief that intervention can have little deterrence or prevention impact. The second misconception follows from the congruence between the justifications given by abusive men and the quasi-justificatory elements of voluntary manslaughter doctrine: the wife-killer who kills in response to his wife's "provocative" conduct is seen as an unlikely recidivist and therefore less dangerous. ${ }^{18}$ The basis for this belief is that the victim's behavior was unusually provocative and since the accused is unlikely to encounter such a provocative wife again, he is unlikely to kill again. ${ }^{19}$ This claim underscores the view of battered women as provocateurs who "call[ this upon [themselves]."20 A quasiself-defense claim is also hidden within the batterer's justifications which reinforces the view that the dynamics of the relationship are to blame for the violence: he killed because he was married to this woman or because he was involved in this relationship, not because of his personal inclination to be violent with female intimate partners.

Scholars analyzing heat-of-passion doctrine have similarly accepted these same assumptions: one rationale for the doctrine holds that

18. C. Robert Showalter et al., The Spousal-Homicide Syndrome, 3 INT'L J.L. \& PsYchiatru 117,139 (1980). See discussion infra note 77 and accompanying text, and infra notes 175.89 and accompanying text.

19. This view may be supported in the courtroom by expert testimony's reliance on interactionist approaches. See, e.g., Adams, supra note 13 (describing family systems models); Michele Bograd, Family Systems Approaches to Wife Battering: A Feminist Critique, 54 AM. J. ORTHOPSYCHIATRY 558, 562 (1984) (Portrayals often paint the abusive husband as a sympathetic characteran "underadequate man"-living with a shrewish "over-adequate" wife. "Overadequate" is a pejorative term, "even though it refers to a battered woman's skills, resourcefulness, and survival abilities ... [In addition,] the term reflects traditional ideals of husband-wife relations: it means simply that the wife has surpassed her husband on some dimension, be it income, occupational status, verbal fuency, or intelligence."); Peter H. Neidig, Women's Shelters, Men's Collectives and Other Issues in the Field of Spouse Abuse, 9 VICTIMOLOGY 464 (1985) (providing an interactionist approach).

20. See, e.g., Ashworth, supra note 6, at 307 where the author states:

Whereas the paradigmatic case of murder might be an attack on an innocent victim, the paradigm of provocation generally involves moral wrongs by both parties. The victim plays an important role in provocation cases, either as instigator of the conflict or by doing something which the accused regards as a wrong against him. Ordinary language reflects this approach, with characteristic phrases such as "he brought it on himself," "she asked for it," and "it served him right." 
increased penalties will not deter heat-of-passion killings, ${ }^{21}$ and a somewhat contradictory rationale suggests that these killers do not pose a serious future threat to society because they are unlikely recidivists. ${ }^{22}$ Yet social science research on domestic violence demonstrates that these beliefs are inaccurate when applied to wife-abuse and wife-killing generally, and are therefore highly questionable when applied to the so-called "provoked" wife-killings. ${ }^{23}$

This article's assessment will include a close examination of a California case, People v. Berry. ${ }^{24}$ The California Supreme Court in Berry overturned a first degree murder conviction by finding that the trial court's failure to give a voluntary manslaughter instruction was reversible error. Berry claimed to have killed in response to provocation caused by his wife's adulterous conduct and her sexual "taunts." The case demonstrates the deleterious effect of the resonance between the excuses and justifications given by abusive men and the cultural (mis)understandings that underlie modern heat-of-passion/adultery doctrine.

Before examining voluntary manslaughter doctrine, it is important to note what I am not saying. I am not saying that a large number of men who kill their wives or lovers "get off" with voluntary manslaughter convictions. In fact, we don't know how many of these defendants are convicted of voluntary manslaughter as opposed to first or second degree murder, ${ }^{25}$ and appellate cases fail, for a number of reasons, to provide the answers. First, many, if not most, appellate cases involving voluntary

21. See Jack K. Weber, Some Provoking Aspects of Voluntary Manslaughter Law, 10 ANGLOAM. L. REv. 159, 171 (1981) ("I think [the loss of self control] has to be such that deterrence is no longer a meaningful consideration.").

22. See, e.g., Note, Manslaughter and the Adequacy of Provocation: The Reasonableness of the Reasonable Man, 106 U. PA. L. REv. 1021, 1040 (1958) ("The way is open for the courts to discontinue the practice of sending those guilty of manslaughter to institutions under the pretense that they require as long a time to become rehabilitated as those who are guilty of murder.").

23. See Ed Stubbing, Police Who Think Family Homicide is Preventable Are Pointing the Way, REsPonse to Victimization WoMEN \& ChildREN, 1990, at 8 (police intervention can deter domestic violence and homicides).

24. 556 P.2d 777 (Cal. 1976).

25. Telephone Interview with Barbara Boland, researcher with the American Prosecutor's Research Institute and leading researcher in the field of homicide (Feb. 13, 1992) (no data exists regarding the sentencing disposition of men who kill wives or lovers); see also Telephone Interview with Professor Franklin E. Zimring, University of California, Boalt Law School, one of the premier researchers with regard to homicide data (Feb. 13, 1992) (not aware of any such data). National data collection combines data on all non-negligent homicide convictions into one group. See Bureau of Justice Statistics, U.S. Department of Justice, Sourcebook of Criminal JusTICE StATistics-1989 390 (Timothy J. Flanagan et al. eds, 1990) [hereinafter SouRCEBooK1989]. 
manslaughter doctrine are appealed on the ground that the court failed to give a voluntary manslaughter instruction. This likely creates a particular bias because in many modern jurisdictions voluntary manslaughter instructions are given freely, thus ensuring that those cases where an instruction is refused involve particularly egregious facts. ${ }^{26}$ Second, the great majority of homicide appellants lose, ${ }^{27}$ and there is no reason to believe that cases where a male defendant killed his wife or lover are exceptions. Third, it is unlikely that a defendant who receives the lesser penalty of voluntary manslaughter will appeal his conviction. Therefore, while significant anecdotal evidence suggests that a voluntary manslaughter defense is successful for many wife-killers, ${ }^{28}$ there is scarce empirical data or relevant appellate information on which to rely to discern the realities of trial court practice. Even without trial court data, however, the analysis of this Article is not undermined. The parallels between the thinking of abusive men and voluntary manslaughter doctrine suggest, at the very least, likely outcomes at trial, and provide a keener understanding of the social context in which abusive men operate.

26. See, eg., People v. Hyde, 212 Cal. Rptr. 440 (1985) (jury instruction on voluntary manslaughter properly refused where defendant drove a stolen police car disguised as an officer making a traffic stop, and then killed the victim-the boyfriend of defendant's ex-girlfriend). Hyde's argument that he killed in the heat of passion because of his extreme jealousy. was rejected by the court because defendant's ex-girlfriend dating another man was not sufficient provocation, and enough cooling time had elapsed to allow whatever passion there was to subside. Id. at 473.

27. Maguigan, supra note 11, at 433 (studies find that only $8.5 \%$ of homicide appeals are discharged or remanded for a new trial (citing Joy A. CHAPPER \& ROGER A. HANSON, NATIONAL Center for State Courts, Understanding Reversible Error in Criminal Appeals: FinAl REPORT 38 (1990)).

28. For example, in a study of men who killed or attempted to kill their wives or lovers, forensic psychiatric researchers noted that even in strict common law jurisdictions, evidence of deliberation and premeditation seldom results in a first degree murder conviction because, "as a practical matter, spouse killers are rarely convicted of first-degree murder." Showalter et al., supra note 18, at 140. Anecdotal newspaper coverage suggests the same conclusion. See, e.g., San Diego County Digest: Escondido, L.A. TIMES, July 9, 1988, at 8 (man was convicted of voluntary manslaughter and sentenced to two years for the murder of his wife because the jury was persuaded by testimony that his wife may have been having an affair); Roxane Amold, Strangled Actress: Did Slayer's Penalty Fit His Crime?, L.A. TIMES, Dec. 3, 1986, at 1 (John Sweeney, convicted of voluntary manslaughter, served 3 years, 7 months and 27 days for killing his girlfriend, Dominique Dunne. The court ruled inadmissible testimony of Sweeney's prior violence against another ex-girlfriend. Sweeney had assaulted Dominique numerous times before, and killed her when she broke up with him. Dominique told friends that she was "frightened of Sweeney and frustrated by his constant attention and jealousy."); Man Sent to Prison in Strangling of Wife, L.A. TIMES, June 28, 1989, at 9 [hereinafter Man Sent to Prison] ("Under a plea agreement, Gary Rubenstein, 32, pleaded guilty to voluntary manslaughter March 3 for killing Mary Hennesy Rubenstein on Aug. 8, 1985, after they had argued.") Ellen Goodman, Why Are the Men Getting Away With Murder?, ARIz. RePUBLIc, May 26,1989 , at A15 (writing about three men convicted of voluntary manslaughter for killing their wives). 


\section{A. Voluntary Manslaughter Doctrine}

Modern United States voluntary manslaughter doctrine is the successor, in large part, to sixteenth and seventeenth century English common law. ${ }^{29}$ The commonplace practice of wearing weapons turned drunken brawls and the settlement of "breaches of honor" into deadly affairs. Difficulties of proof in the self-defense context, and the belief that capital punishment was an unfair result for those who killed in mutual combat, prompted jurists to mitigate the crime of murder to manslaughter where the defendant was shown to have acted in "the heat of passion." ${ }^{30}$ The four necessary elements established by the common law still shape much of modern voluntary manslaughter doctrine: (1) a provocation that would arouse a reasonable man to the heat of passion; (2) the defendant actually was aroused to the heat of passion; (3) a reasonable man would not have cooled off; and (4) the defendant did not, in fact, cool off. ${ }^{31}$

Generally, the doctrine requires that the "passion" disturb the defendant's reason to such an extent that an "ordinary person[ of average disposition [would] likely . . . act rashly or without due deliberation and reflection, and from passion rather than judgment."32 "Passion" has usually meant "anger," though some jurisdictions have consistently included fear and jurisdictions that follow the Model Penal Code include any "extreme mental or emotional disturbance." ${ }^{33}$ Revenge, however,

29. See generally Joshua Dressler, Rethinking Heat of Passion: A Defense in Search of a Rationale, 73 J.L. \& CRIMINOLOGY 421, $425-29$ (1982) for a brief history of early voluntary manslaughter doctrine.

30. Id. at 426.

31. 93 ALR 3d 925 \& 2, at 927 (1979) ("a homicide, even though intentional, is regarded as the lesser crime of voluntary manslaughter where the killing was committed under the infuence of passion produced by an adequate or reasonable provocation and before a reasonable time has elapsed for the passion to cool and reason to assume control. ...."). See also Wharton's Criminal LAw $\S 165,262$ (Charles F. Thorera ed., 1979):

In summary, if there is evidence of provocation, and if the court regards such provocation as potentially adequate, the jury must inquire: (1) Whether the defendant was in fact in the heat of passion; (2) Even if the defendant was in the heat of passion, would the provocation have induced passion in a reasonable man; (3) Even if the provocation would have induced passion in a reasonable man, was there such a time interval that the passion of the defendant had in fact cooled; (4) Even if the defendant's passion had not in fact cooled, given the time interval, would the passion of a reasonable man have cooled.

32. 17 Cal Jur 3d (Rev.) Part 1, Criminal Law $§ 255$ (1984). See also Wharton's Criminal LAW, supra note 31 , at 239 ("The passion aroused by the provocation must be sufficiently extreme to dethrone reason and prevent cool reflection.").

33. MOdel PenAl CODE $\S 210.3$ (commentaries) ("criminal homicide constitutes manslaughter when: . . . a homicide [is] . . committed under the infuence of extreme mental or emotional disturbance for which there is reasonable explanation or excuse ... determined from the viewpoint of a person in the actor's situation under the circumstances as he believes them to be"). 
can never be an adequate motivation to mitigate murder to manslaughter, revenge being consistent with premeditation and wholly inconsistent with an act committed under the "sway" of passion. ${ }^{34}$

The common law measure of what would arouse a "reasonable man" to such a passion became a question of law, evolving into fixed categories of "adequate" provocation. The "nineteenth century four"35 came to define "adequate provocation" in the courts of the United States: (1) a violent assault; (2) an unlawful arrest; (3) mutual combat; (4) the sight of the accused's wife in the act of adultery. ${ }^{36}$

\section{Adultery Category}

The "adultery category" was recognized in the earliest cases as the highest form of provocation. In fact, one of the earliest cases to delineate the various forms of "adequate provocation," notes that adultery is the "highest invasion of property" and thus represents the "highest" form of provocation. ${ }^{37}$ Similarly, the seventeenth century Manning's Case, ${ }^{38}$ one of the earliest examples of an adultery category voluntary manslaughter conviction, ordered that defendant Manning have the benefit of clergy and be burned in the hand, ${ }^{39}$ directing the executioner to "burn him gently, because there could be no greater provocation than this."40 The American experience was no different. Perhaps the first American case

34. Wharton's CRIMINAL LAW, supra note 31, at 402:

To be sufficient to reduce a homicide to manslaughter, the heat of passion must be such as would naturally be aroused in the mind of an ordinary, reasonable person, under the given facts and circumstances, or in the mind of a person of ordinary self-control. The inquiry is whether the defendant's reason was so disturbed or obscured by passion that would render an ordinary person of average disposition liable to act rashly or without due deliberation and reflection, and permits passion rather than firm judgment.

See also People v. Valentine, 169 P.2d 1 (Cal. 1946):

For the fundamental of the [heat of passion] inquiry is whether or not the defendant's reason was, at the time of his act, so disturbed or obscured by some passion-not necessarily fear and never, of course, the passion for revenge-to such an extent as would render ordinary men of average disposition liable to act rashly .... .

Id. at 12 (emphasis added).

35. Note, supra note 22 , at 1023-24.

36. The adultery category would mitigate both a killing of the wife or of her lover. Id.

37. Regina v. Mawgridge, 84 Eng. Rep. 1107, 1115 (1707).

[J]ealousy is the rage of a man, and adultery is the highest invasion of property ... If a thief comes to rob another, it is lawful to kill him. And if a man comes to rob a man's posterity and his family, yet to kill him is manslaughter. So is the law though it may seem Id. hard, that the killing in the one case should not be as justifiable as the other.

38. 83 Eng. Rep. 112 (1671).

39. The purpose of the burning was to record that Manning had the benefit of clergy. Manning's Case, 83 Eng. Rep. 112 (1671).

40. Id. 
to develop the concept of the "reasonable man" in a homicide trial involved adultery-related attempted murder. ${ }^{41}$

Modern reformation of voluntary manslaughter doctrine has, if anything, tended to expand the circumstances under which the "adultery category" applies. While some jurisdictions have strict rules requiring that the act of adultery be actually witnessed by the defendant, or that the couple be married as opposed to unmarried lovers ${ }^{42}$-the modern trend away from strict categories to a "reasonableness" standard has allowed wife killers to include a wider range of circumstances. ${ }^{43}$ Nevertheless, the doctrine is still generally tied to an "objective standard"which ties it to some measure of community norms. ${ }^{44}$ The Model Penal Code (MPC) provides the most dramatic departure from the common

41. Maher v. People, 10 Mich. 212 (1862). The killing of a wife's male lover has historically received even greater sympathy. At one time Georgia, New Mexico, Texas, and Utah provided that it was justifiable homicide to kill a wife's lover. See, e.g., Reed v. State, 59 S.W.2d 122 (Tex. 1933) (finding that a wife who killed her husband's lover could not receive the benefit of a state statute that provided that a husband's homicide of "one taken in the act of adultery with his wife" was justifiable homicide); 71 Tex. Penal CODE ANN. art. 1220 (1936). Some jurisdictions limited justification to cases involving the prevention of adultery, finding homicides committed after adultery was completed to be voluntary manslaughter. See, e.g., Scroggs v. State, 93 S.E.2d 583 (Ga. 1956) (the court held that there was sufficient evidence to support a finding that the defendant killed the victim to prevent sexual relations between her husband and the victim, thus the killing was justified); Mays v. State, 14 S.E. 560 (Ga. 1891). But at least one state supreme court actually endorsed jury nullification in cases involving after-adultery killings of the wife's lover. See Biggs v. Georgia, $29 \mathrm{Ga} .723$, 728 (1860) ("[i]s it not [the jury's] . . . right to determine whether in reason or justice, it is not justifiable in the sight of Heaven and earth, to slay the murderer of the respectability of a family, as one forcibly attacks habitation and property?"). See Note, supra note 22, at 1029 n.61 (citing DEL. CODE ANN. tit. 11, §575(a) (1953)) (noting that in Delaware killing the paramour received far less punishment than killing the wife: $\$ 10,000$ fine and thirty years for killing the wife compared with $\$ 100$ fine and one year in prison for killing the paramour).

42. See, e.g., People v. Chevalier, 544 N.E.2d 942 (Ill. 1989) ("In Illinois, adultery with a spouse as provocation generally has been limited to those instances where the parties are discovered in the act of adultery or immediately before or after such an act, and the killing immediately follows such discovery."); People v. McDonald, 212 N.E.2d 299 (Ill. 1965) (Even where the provocative act is the direct, unexpected and visual discovery of sexual intercourse in progress, the heat of passion defense is still only available to the cuckold who is a lawful spouse).

43. See KADISH \& SchulHOFER, supra note 7, at 442 ("The restrictive view [of what constitutes legally adequate provocation] has now given way, in most jurisdictions, to [a broader view]: The manslaughter issue must be left to the jury whenever the evidence shows any circumstances (whether by conduct or by words alone) that might cause a reasonable person to lose self-control."); Tripp v. Maryland, 374 A.2d 384 (Md. 1977) ("The modern tendency is to extend the rule of mitigation beyond the narrow situation where one spouse actually catches the other in the act of committing adultery.").

44. Kadish \& Schulhofer note that: "Few, if any, states have adopted an entirely subjective standard of provocation. The model penal code retains an objective element, but qualifies it by specifying that murder is reduced to manslaughter only when committed under the influence of an extreme mental or emotional disturbance for which there is a reasonable explanation or excuse." KADISH \& SCHULHOFER, supra note 7, at 442. 
law's categories of "legally sufficient" provocation, but still maintains a variant of the objective/subjective test, requiring that the "extreme mental or emotional disturbance" have a "reasonable explanation or excuse". 45

\section{II. "INNOCENT" KILLERS V. "IN COLD BLOOD": MEN WHO BEAT AND MEN WHO KILL}

It is specious to draw a line between domestic violence assault and spousal homicide as if they were two quite distinct, separate species. They are not, instead they are often one and the same event, along a continuum of violence distinguished only by inter alia the force and number of blows, where the knife plunged or bullet embedded. ${ }^{46}$

In those areas in which there is a good "fit" between social understandings and legal doctrine, the doctrine remains largely unexamined, its assumptions unquestioned. ${ }^{47}$ Such a "fit" is found between the social expectation that a man will be enraged at a wife or lover's sexual infidelity, on the one hand, and the legal doctrine of voluntary manslaughter/

45. The "[r]easonableness of such explanation or excuse shall be determined from the viewpoint of a person in the actor's situation under the circumstances as he believes them to be." MODEL PENAL CODE § 210.3(1) (Proposed Official Draft 1962). The majority of states continue to use variants of common law heat of passion doctrine, though a significant minority have adopted the MPC language. Dressler, supra note 29, at 432 . Dressler also notes that in 1982, 49 states had voluntary manslaughter statutes. $I d$. at 422.

46. 'Susan S. M. Edwards, $A$ Socio-legal Evaluation of Gender Ideologies in Domestic Violence Assault and Spousal Homicides, 10 Victimology 186 (1985).

47. This is not the case when it comes to analysis of the applicability of voluntary manslaughter doctrine to defendants who vary from the "reasonable man" standard-too often been defined as white, able-bodied, male, and heterosexual. See, e.g., Dolores A. Donovan \& Stephanic M. Wildman, Is the Reasonable Man Obsolete? A Critical Perspective on Self-Defense and Provocation, 14 LOY. L.A. L. REv. 435 (1981) (criminal law's reasonable man standard makes the experiences of women and other minority group defendants invisible); Note, The Cultural Defense in Criminal Law, 99 HARV. L. REv. 1293, 1300 (1986) (arguing for a "formal cultural defense" within substan: tive criminal law in order to better reflect cultural differences of defendants). Laurie Taylor provides a very thoughtful critique of voluntary manslaughter doctrine's application to female defendants. Taylor, supra note 6, at 1679 ([T] he legal standards that define adequate provocation and passionate 'human' weaknesses reflect a male view of understandable homicidal violence."). Furthermore, there are a few notable exceptions to this general silence regarding adultery/manslaughter law. See, e.g., John Kaplan \& Robert Weisberg, Criminal Law: CaSes and Materials 261-68 (2nd ed. 1991) (examining gender and voluntary manslaughter doctrine); Law Women Find Sexism in $1 L$ Casebook, The COMMENTAToR, New York University Law School, Mar. 19, 1984, at 7 (as quoted in John Kaplan \& Robert Weisberg, Criminal Law: Cases and Materials, 263 (1st ed. 1980)) (noting that "[t]he common thread running through the majority of the cases in this section [of criminal law casebooks discussing voluntary manslaughter] involves men defending their virility with violence ... [I]f the provocation rule is used primarily as a defense by men who resort to violence when they feel their masculinity has been threatened, what values are being reflected and perpetuated by the provocation rule?"); Taylor, supra note 6, at 1696 ("The law of provocation 
heat-of-passion law as applied when the accused claims he was provoked by his wife's adultery. ${ }^{48}$ The historical common law category of adultery as the paradigm example of provocation adequate to render a killing voluntary manslaughter reflects this social expectation, and together-the interaction of the social understanding with the legal doctrine-hides the degree to which "adultery killings" are really like other wife-killings.

The research relevant to the study of men who kill their wives is currently divided into two perspectives: first those researchers whose primary orientation is the study and treatment of battering men and who view murder as an extreme point on a continuum of abusive conduct; ${ }^{49}$ second, those who focus on the study of inter-sexual homicides, this latter group being comprised mostly of criminologists, sociologists, and forensic psychiatrists. ${ }^{50}$. Efforts to correlate the two bodies of data and analysis have been rare.

endorses men's ownership of women's sexuality by expressly sanctioning violent reactions by husbands to their wives' infidelity."). For more general critiques of the "reasonable person" standard see Weber, supra note 21.

For an article making an analysis similar to mine in the context of voluntary manslaughter doctrine's application to homicides "provoked" by homosexual sexual advances, see Robert B. Mison, Homophobia in Manslaughter: The Homosexual Advance as Insufficient Provocation, 80 CAL. L. REV. 133, 135 (1992) (the provision for a voluntary manslaughter jury instruction where the defendant claims provocation by a nonviolent homosexual advance is "immoral and inconsistent with the goals of modern criminal jurisprudence").

48. Though the jealous killing of a wife (i.e., "love-triangle killings") is one of the primary cultural stereotypes of a "heat of passion" killing and adultery is a primary stereotype of law when it comes to defining adequate provocation, in truth, wife-killings actually account for a very small percentage of murders. The vast majority of murders are men killing men. In 1988 males represented approximately $75 \%$ of all homicide victims and $60 \%$ of the perpetrators. SOURCEBOOK1989, supra note 25 , at 390-391, Table 3.130 . In 1988, 675 husbands and boyfriends were killed by their partners compared with 1,406 wives and girlfriends. This represented $3.7 \%$ and $7.7 \%$, respectively, of the total number of homicide victims. Id. at 387, Table 3.127. (These figures may represent underestimates because the data includes 5,992 homicides (32.8\%) in which the relationship was unknown.). Zimring notes that male on male homicides are the most likely category to experience sharp increases in rates of homicides while inter-sexual killings remain at a fairly stable rate. Zimring et al., supra note 2, at 913, 916.

49. See, eg., Barbara Hart, Beyond the "Duty to Warm": A Therapist's "Duty to Protect" Battered Women and Children, in Feminist PERSPECTIVES ON WIFE ABUSE, supra note 3, at 234, 240 (providing a list of factors to be used by therapists in evaluating an abusive man's potential lethality); Sonkin \& Fazio, supra note 8 (describing the use of expert testimony regarding battering men in the context of criminal homicide prosecutions of men who kill wives or lovers).

50. See, e.g., Marvin Wolfgang, Patterns in Criminal homicide 203-21 (1958) (sociological study of spousal homicides); George W. Barnard et al., Till Death Do Us Part: $A$ Study of Spouse Murder, 10 Bull. AM. ACAD. PsychiaTRY \& L. 271 (1982) (study of 34 offenders psychiatrically evaluated for court); Showalter et al., supra note 18 (study of 11 offenders referred by court); Robert A. Silverman \& S.K. Mukherjee, Intimate Homicide: An Analysis of Violent Social Relationships, 5 BeHavroral SCI. \& L. 37 (1987) (sociological study examining police spousal-homicide reports); Zimring et al., supra note 2 (analysis of 151 intersexual homicides in Chicago). 
In this section, I will discuss what we know about men who are identified as "abusers" and what we know about those men who kill their wives or lovers. Evidence strongly suggests that, at the very least, these two groups significantly overlap. This evidence includes the similarity of the explanations given by abusers and those given by wife-killers regarding their motivation to kill; data that suggests that in the majority of domestic violence killings, the male killer has a history of violence with the homicide victim; and studies that show that police have been called to the scene of a husband-wife homicide several times prior to the occurrence of the homicide.

There may exist a group of killers to whom this data does not apply. Heat-of-passion doctrine is predicated on just such a claim: a provoked killer, of "average disposition" and ordinary self-control" for whom violence is an uncharacteristic act. This article does not attempt to refute the general claim that such killers exist, but rather suggests that its applicability is strained when it is used to describe men who kill their female partners. I will show that similar claims of provocation have been made regarding wife beating generally and are demonstrably false. Additionally, the close association of wife-killing with heat-of-passion law has created a dynamic in which the general social construction of wife-killing as an "uncontrollable" response provoked by bad conduct reinforces and is also reinforced by the doctrine's view of adultery related wife-killings. This interaction suggests that if the general social construction of wifekilling is premised on misconceptions, then application of those same conceptions to adultery killings, are likely to be equally false.

\section{A. Men Who Batter}

\section{The Issue is Control}

I will begin with what we know the most about: men who are identified as "batterers." First, a batterer's pattern of conduct is frequently repeated in his different romantic relationships with women. ${ }^{52}$ Contrary to those views which stress the dynamics of a given relationship, it

51. See, e.g., People v. Cooley, 211 A.2d 173 (Vt. 1962); People v. Rich, 755 P.2d 960 (Cal. 1988), cert. denied, Rich v. California, 488 U.S. 1051 (1988).

52. See, e.g., Sonkin \& Fazio, supra note 8, at 222-23 (" $[\mathrm{A}]$ person who has an already established pattern of woman beating or child abuse is likely to continue such abuse unless there is some intervention, such as criminal justice sanctions and/or treatment."); Crites \& Coker, supra 10, at 12 13 (abusers are likely to repeat their abusive behavior in subsequent relationships); Daniel G. Saunders, Child Custody Decisions in Families Experiencing Woman Abuse, Soc. WoRK (forthcoming Sept. 1993) (studies indicate that the likelihood of a batterer abusing in a new relationship to be between $57 \%$ and $86 \%$ ). 
appears that an abuser is likely to bring the violence with him to each new romantic encounter. Second, much of current literature on battering notes that the violence, contrary to earlier psychoanalytic explanations, is instrumental rather than expressive. ${ }^{53}$ In other words, the violence is not only an expression of rage, but serves a purpose. In general, that purpose is to control his wife or lover, to gain compliance with his demands. ${ }^{54}$ I will discuss the purposeful nature of violence directed against wives more fully in Section III, but it is important here in identifying the systemic quality of the violence to note that it is neither random nor is it isolated conduct. It is part of a system of control and is frequently accompanied by threatening behavior, destruction of property, sexual, verbal, and economic abuse. ${ }^{55}$

The instrumental nature of the violence can be seen in the manner in which battering men describe their motivations for violence. Abusive men blame their violence on complaints about the woman: she's a bad housekeeper; she doesn't show the men the proper deference; she's verbally aggressive; she's a poor mother. ${ }^{56}$ Sexuality figures prominently in most of these complaints: she's not sexually responsive enough; she isor desires to be-sexually unfaithful..$^{57}$ The women, in turn, describe abusive partners or ex-partners as extremely possessive, suspicious, and jealous; ${ }^{58}$ and clinicians describe the men as "pathologically" jealous. 59

53. Ptacek, supra note 3, at 142-51.

54. Dobash \& Dobash, supra note 3 , at 274 . (The violence is frequently a response to the man's perception that his lover is questioning his authority, "challenging the legitimacy of his behavior," or asserting her autonomy.)

55. "[Battering] is a cohesive pattern of coercive controls that include verbal abuse, threats, psychological manipulation, sexual coercion, and control over economic resources." Adams, supra note 4, at 13-14. The violence is an "integral part of a continuing relationship." Dobash \& Dobash, supra note 3, at 272-73. When understood in the context of power and control, the violence is not an isolated act, but rather a part of a system intended to control the woman. Sonkin \& Fazio, supra note 8, at 228-29; Ellen Pence \& Michael Paymar, Power and Control: Tactics of Men Who Batter (Minnesota Program Development, Inc., Duluth, Minn.) 1986. Paymar and Pence suggest that abusive men use the following "tactics" of power and control: emotional abuse; isolation; threats including threats of suicide, taking the children, having the woman committed, leaving her penniless, killing or mutilating her or her family; economic abuse, using children either through manipulation or by threatening to keep them from her; intimidation; use of male privilege; sexual abuse, and, physical violence. $I d$.

56. Ptacek, supra note 3, at 146-48.

57. See supra note 3 and accompanying text.

58. Adams, supra note 4, at 14 (noting that "[m]any battered women report that their husbands make frequent jealous accusations. For some abusers, this jealousy has an obsessive quality. . . . [The] presence [of pathological or obsessive jealousy] should be seen as a significant indicator of the potential for homicide."); LENORE E. WALKER, THE BATTERED WOMAN 114 (1979) ("Sexual jealousy is almost universally present in the battering relationship."); Dobash \& Dobash, supra note 3, at 273 (reporting that among sources of conflict leading to a violent episode, 
The control of the woman's sexuality also extends to sexual abuseabuse that may become extreme such as rape, forced sex with animals or other men, and physical attacks on the woman's sex organs or breasts. ${ }^{60}$

The following story is typical of the accounts women give of the men's "pathological" jealousy:

He figured out it took 30 minutes exactly for me to get from work back home. I could never go out for a drink with the other women in the office. I could barely chat on the way out to the parking lot. God help me if there was a traffic jam or if a train came across town and blocked the road. He'd be pacing in the driveway, tapping his watch, ready to accuse me of having an affair after work. ${ }^{61}$

To understand the full impact of this kind of extreme jealousy, it must be viewed in a context which includes many other control tactics. ${ }^{62}$ The result of the whole is to limit the woman's social contacts, to isolate her. Friendships with other women are discouraged; activities that cannot be closely monitored are denied. ${ }^{63}$

Extreme jealousy is a powerful tool for control in two distinct ways. First, by calling on the social understanding available to the man who punishes a woman who has humiliated him by making him a "cuckold," the abusive man draws upon one of our most powerful cultural stereotypes; the blameworthiness of his violence is thus mitigated. Second, it serves to directly control his wife's daily behavior by monitoring who she sees, who she talks to, how she dresses, who her friends are, or whether or not she has any friends. ${ }^{64}$

battered women related that "possessiveness and sexual jealously" accounted for $45 \%$ of the "typical" episodes); Brisson, supra note 2, at 341 (41\% of abusive men studied mentioned jealousy as preceding their violence); Sonkin \& Fazio, supra note 8, at 223 ("Many battered women describe their partners as suspicious to the point of severely curtailing their freedom to participate in out-ofhome activities.").

59. See Adams, supra note 4, at 14 (Many abusers are jealous, but for some this jealousy is "pathological" or they demonstrate "extreme possessiveness" which, when the woman leaves, results in "ongoing harassment and pressure tactics, homicide and suicide threats, uninvited visits at home and work, and manipulation of children."); Sonkin \& Fazio, supra note 8, at 223.

60. See William Stacey \& Anson Shupe, The Family Secret: Domestic Violence in AMERICA 32-33 (1983) (one in four of abused women studied reported sexual abuse including rape, mutilating the woman's genitals and breasts, excessive sexual demands enforced by the threat of physical assault and frequently accompanied with accusations of infidelity); WALKER, supra note 58 (citing incidents of bestiality and sexual sadism).

61. STACEY \& ShUPE, supra note 60 , at 51 .

62. Pence \& Paymar, supra note 55 (listing tactics of power and control). .

63. STACEY \& SHUPE, supra note 60 , at 50.

64. Adams, supra note 4, at 14 ("Accusations of infidelity or of neglecting the family serve to manipulate the woman into curtailing her contacts with friends, co-workers, and relatives."). 
Extreme jealousy is but one tool of control utilized by the batterer. Battered women tell similar stories of having to account for every dime they spend, something they attribute to the man's fear that they are saving money in order to leave him. ${ }^{65}$ This connection between the degree to which the man controls his lover's actions and the degree to which he fears losing her is also referred to in the literature on battering. ${ }^{66}$ The more fearful he is of losing the woman, the more coercive and controlling his behavior becomes, creating an increasingly powerful incentive for the woman to leave him, resulting in an escalating circle of violence and control. ${ }^{67}$ The controlling behavior may not pay off in the long run, but it is clearly reinforced in the short run: it insures compliance, it maintains dominance, it feels powerful, and it diminishes the woman's ability to leave. The idea that a struggle for control is at the heart of battering is further underscored by the fact that women are in the greatest danger when they leave a battering relationship: over half of those who are killed are separated at the time. ${ }^{68}$

\section{Obsessiveness and Centrality of the Woman}

Literature on battering has examined the murder of wives and lovers primarily from the standpoint of prevention, identifying characteristics that increase a particular man's lethality. For example, Barbara Hart identifies the following factors as important in measuring an individual man's likelihood of committing murder: his obsession with his partner, the centrality to his life of the relationship with the woman, drug and alcohol consumption, access to weapons, threats of homicide or suicide, fantasies of homicide or suicide, access to the woman, and pathological jealousy. ${ }^{69}$

65. Accounts of women in Maluhia O'Wahine, Family Violence Program in Honolulu, Hawaii (on file with author).

66. See generally Adams, supra note 4, at 13 ("Women are most likely to be murdered while attempting to ... leave an abusive relationship.").

67. Id.

68. Barnard et al., supra note 50 , at 275 (finding that $56.5 \%$ of male domestic killers were separated at the time of the homicide.); Mahoney, supra note 2 (the term "separation assault" defines this most lethal form of attack).

69. Hart, supra note 49 , at 241-42; see also Adams, supra note 4, at 14 stating that:

[pathological jealousy] . . . should be seen as a significant indicator of the potential for homicide. [references omitted.] Closely related to this is extreme possessiveness which is often manifested by the abuser's unwillingness to accept the end of the relationship. Women who leave this type of man are subjected to ongoing harassment and pressure tactics including multiple phone calls, homicide or suicide threats, uninvited visits at home or work, and manipulation of the children. 
Obsessiveness and the centrality of the woman are two particularly important factors indicating "lethality." When a woman leaves, obsession with her may be manifested through "courting" kinds of behavior (e.g., frequent phone calls, flowers) or through persistent threats and "stalking" behavior. ${ }^{70}$ This suggests that the killings committed by men who could have been identified as "batterers," had the assessment been applied prior to committing homicide, are not the result of impulsive behavior, but instead follow a long period of obsessive thinking marked by rehearsal-either in the form of homicidal fantasy or in the form of actual assaults similar in nature to the ultimate act of killing. "Deliberation," as defined by many first degree murder statutes, may fail to capture the nature of this obsessive thinking. ${ }^{71}$ Our oppositional definitions of "premeditation" and "impassioned" killings fail to capture the nature of this phenomenon which is both premeditated in its obsessive quality and "impassioned" in that the killer believes himself to be "out of control." The man "may have fantasized events that would 'trigger' him to commit homicide," rehearsing the killing, though not planning it in a straight-forward cognitive fashion. ${ }^{72} \mathrm{He}$ may describe feeling that his choice to kill is completely in the hands of fate or, perhaps more accurately, in the hands of the victim..$^{73}$ If she continues to do " $x$," or if she refuses to do " $x$," then he will "have no choice" but to kill. These men may be heard to say with some resignation, "one of us is going to end up dead."74 The sense of no control is easily demonstrated to be false, of course. For like the man who blames his abusive behavior on drinking, yet continues to frequent places where drink is plentiful, these men take no responsibility for avoiding circumstances which they claim provokes

70. Hart, supra note 49, at 242 (A woman's attempts to separate are often thwarted by her partner's inability to "let go": he will track her down, often forcing her to return home. Long after she leaves he may continue to threaten her, the children, or other family members, if she does not return; alternatively, he may make repeated and earnest attempts to convince her to reconcile because he has changed).

71. For example, a statute such as Tennessee's which provides that a "deliberate act" is "one performed with a cool purpose" and a "premeditated act" is "one done after the exercise of reflection and judgment" is meant to distinguish the deliberate killer from one who kills under the "heat of passion." See TENN. CODE ANN. $§ 39-13-201$ (1991) ("The definition of 'a deliberate act' is that the act be one committed with 'a cool purpose' and without passion or provocation. This latter phrase is designed to allow the defendant who kills another with passion or provocation to be adjudged guilty of either second degree murder or voluntary manslaughter ....") Yet, the man who kills his wife may be both "impassioned" and calculating. See infra notes 216-20 and accompanying text (describing murder defendant Berry's conflicting statements regarding whether or not he planned to kill his wife).

72. Hart, supra note 49 , at 241 .

73. Interviews with battering men in Komo Mai, a Honolulu-based program (on file with author).

74. Id. 
them to uncontrolled rage. Instead, they "toy" with the idea of killing, becoming increasingly obsessive about the wrong done them by the victim and eventually convinced that "something must be done to make things right." This kind of quasi loss of control can be very attractive, for "[by] experiencing himself as an object controlled by transcendent forces, an individual can genuinely experience a new or different world."75

\section{Police and Criminology Studies: Battering Men and Killers}

Police and criminology studies are the works that best bring together the analysis of the battering literature with information regarding men who kill. Contrary to "[ $t]$ he popular image of the model citizen who one day goes berserk and kills a family member[,]"76 police studies have consistently found that men who kill their female partners have a history of violent behavior. ${ }^{77}$ Roughly $70 \%$ to $75 \%$ of domestic homicide offenders have been previously arrested and about $50 \%$ have been convicted for violent crimes. ${ }^{78}$ The frequently cited Kansas City study of spousal homicides found that in $90 \%$ of the cases the police had been called to the home a median of 5 times in response to "domestic disturbance" calls. ${ }^{79}$

75. Jack Katz, Seductions of Crime: Moral and Sensual Attractions in Doing EVIL 8 (1988).

76. Gary Kleck, Policy Lessons from Recent Gun Control Research, LAW \& ConTEMP. ProBs., Winter 1986, at 35, 40. See also KATZ, supra note 75, at 39 (contrary to the assumption that mounting rage spills over into violence, "close accounts [of the killing] reveal a frequent pattern in which an assailant moves into an attack and then rage builds"); Gary Kleck \& David J. Bordua, The Factual Foundation for Certain Key Assumptions of Gun Control, 5 LAW \& PoL'y Q. 271, 291 (1983).

77. KATZ, supra note 75 , at 38 (about $80 \%$ of those arrested for murder or non-negligent homicide in 1970 had previous arrests and of those arrested between 1970 and 1975, almost $70 \%$ had prior arrest records). Katz describes these killings as sacrificial, noting that "[t]he attackers, however wild and impassioned they appear at the moment, know deeply and in some detail just what they are doing. The typical killer is familiar with the victim, feels at home in the setting, and has often practiced variations on the themes of sacrificial violence." Id. at 39. See also Kleck, supra note 76, at 41 ("Rather than being isolated outbursts, violent acts are almost always part of a continuing pattern of violent behavior, whether the violence is spouse or child abuse or armed robbery committed by "hardened criminals." ").

78. KATZ, supra note 75 , at 38 .

79. Kleck, supra note 76, at 41. See also Lawrence W. Sherman \& Richard A. Berk, The Minneapolis Domestic Violence Experiment, Washington, D.C.: The Police Foundation (1984) (reporting that arrest was twice as great a deterrent as was the practice of mediating domestic violence assaults). Police studies have also found that if the police arrest, they are likely to deter further violence. See, e.g., Stubbing, supra note 23 (family homicides dropped from nine in 1984 to two in 1988 in Newport News, Virginia and from 13 in 1985 to an average of 8 per year for the years 1988-1990 in Albuquerque, New Mexico as a result of police department arrest policies.). See also infra notes 137-38 and accompanying text. 
Though the popular image of the man who kills his wife is someone who "suddenly cracked" 80 under the strain, this is clearly not the case when the accused fits the description of a battering man. This violence is purposeful conduct committed by a man who has a history of assaulting the victim. However, the conception of the man pushed beyond his limits is the thread that ties our cultural conceptions of domestic violence together with those reflected in voluntary manslaughter doctrine.

\section{B. MeN Who KILL}

Research regarding men who kill wives or lovers is not extensive, and qualitative research which examines the motivations of the accused is even more limited. ${ }^{81}$ Additionally, those studies which do examine motivations typically carry an inherent bias related both to the purpose of the research and to the manner in which the subjects are selected. These studies are generally carried out by psychiatrists to whom the subject has been referred either by the defense counsel or by the court. The court is more likely to refer those men whose sanity is an issue. Not surprisingly, the research of predominately defense-side forensic psychiatrists may carry a defense bias. ${ }^{82}$ Even were this not the case, the process of selection for court referral necessitates judicial and defense counsel judgment calls regarding the various potential defenses available for the defendant-i.e., insanity, diminished capacity, heat of passion. Though the absence of comparative data makes certainty impossible, it is likely that the samples are thereby further skewed in the direction of referrals for defendants whose stories more nearly fit judicial and general social stereotypes of "heat-of-passion" killings. This "turn" to the sampling is further exaggerated by the dismissal from the study of those who are

80. See, Goodman supra note 28 (Dong Lu Chen was sentenced to five years for killing his wife. ("The man cracked, said the judge, adding: 'He was a product of his culture.' The man was Chinese; the wife was unfaithful.").

81. Attempts to gather quantitative data on motivations for male-perpetrated intimate homicides have necessarily relied largely on police reporting and frequently relate to all inter-sexual homicides. See, e.g., Silverman \& Mukherjee, supra note 50, at 42 (finding the three biggest categories of events which precipitated an intersexual homicide to be such non-descript categories as: an argument (55\%); unknown (24.6\%); and other (15.1\%). "[With regard to motive] the information on the police reports is tentative at best and second, it usually consists of police opinion or is one sided (the other side being dead)." Id. at 44.

82. See Showalter et al., supra note 18, at 119 ("[a]ll of these clients [included in the study ... .] were referred for forensic evaluation by their attorneys ... who had special interest in the offender's mental state at the time of the offense") (emphasis added). 
clearly insane, ${ }^{83}$ thereby producing a sample of sane defendants whose chances of fitting some classic description of "heat-of-passion" has been greatly increased. While such a sample cannot purport to be a study which represents the entire group of men who kill their wives, lovers, or ex-wives and lovers, it does shed light on the subject. These studies provide an opportunity to examine the way in which the killers' explanations for their violence, as well as the explanations attributed to their violence by mental health professionals, are shaped by the intersection of the mental health profession and law. The result, then, is a research sample-distilled and bent-to more nearly reflect "classic" heat of passion stories. This provides an excellent opportunity to test the concepts of this paper, for if we are to find the classic heat of passion wife-killer-i.e., the man who "suddenly" kills under the "sway" of passion, for whom violence is an uncharacteristic act and therefore the result of circumstances rendering him "out of control"-we would expect to find him in these studies. In fact, what we find are wife-killers who look much like wife batterers.

Approximately $60 \%$ of men who kill their wives allege that she was sexually unfaithful and over $50 \%$ say that she deserted them. ${ }^{84}$ One study concludes that the most common type of homicide committed by men who kill their wives is a "sex-role threat homicide" in which "[a] walkout, a demand, a threat of separation . . . represent [to the men] intolerable desertion, rejection, and abandonment."85 This study's description of the wife-killers sounds remarkably similar to battering literature's description of batterers: emotionally dependant on their partner; controlling of her movements and behavior; extremely jealous and possessive; experiencing her attempts to separate as intolerable desertion requiring a violent response; likewise responding with violence to a perceived rejection of their "rightful" dominance. ${ }^{86}$

83. Id. (Showalter et al. determined that 6 of 17 referrals were not suitable for the study because "the homicidal behavior was ... secondary to a serious psychiatric disorder or serious longstanding character pathology .....").

84. Barnard et al., supra note 50, at 274; see also Showalter et al., supra note 18 , at 129 (finding that all of the 11 men studied claimed that their partner/victim was unfaithful).

85. Barnard et al., supra note 50, at 274-275, 277. The following story illustrates the intertwining of motivations related to desertion and response to the woman's rejection of the man's dominance: "A male prisoner related a long and elaborate chain of fears of desertion and suspicion of infidelity on the part of his wife. He followed her for days and ended up murdering her when she insisted she 'must have more freedom' so she could go alone to a nearby health spa." Id. at 279. But see Silverman \& Mukherjee, supra note 50, at 42 (reporting that their Canadian research found only $5 \%$ of men who killed intimates claimed that the victim was sexually promiscuous. However, this finding relied solely on police homicide reports rather than interviews with the accused).

86. See supra text accompanying note 56; infra notes $140-44$ and accompanying text. 
Another study by Showalter, however, more nearly matches the stereotype of the impassioned killer. ${ }^{87}$ Showalter's study consists of eleven men referred by their defense attorneys for a psychiatric evaluation. The focus of the defense counsel's strategy was the state of mind of the defendant at the time of the offense. ${ }^{88}$ Though Showalter's sample is small, he argues that the striking similarity between the 11 subjects suggests that they are "characteristic of a large proportion of spousal homicide cases." 89 Showalter describes a "spousal-homicide syndrome" leading to killings that are "classic illustrations of victim-precipitated homicides." 90 The subjects in Showalter's study are men who were relentlessly tormented by unforgiving wives or girlfriends who taunted them about their sexual inadequacies and flaunted their own affairs with other men. In summary, Showalter's description tracks closely the heat of passion stereotype of an "adultery category" voluntary manslaughter case. On closer examination however, despite Showalter's conclusion that these men are "clearly differentiat[ed] . . . from the stereotypical murderer,"91 his findings provide remarkable similarities to descriptions of battering men in the battering literature that tend to belie the "heat of passion" categorization. For example, with regard to prior acts of violence, all but one of the men admitted making prior threats of assault on their wives. ${ }^{92}$ Further, the relationships are described as "a central feature in the life of the offender"93 suggesting an obsessiveness with the woman and emotional dependency characteristic of abusive men. ${ }^{94}$ In $72 \%$ of the cases the defendant and victim were separated at the time of the assault and the woman's threat of a final withdrawal from the relationship precipitated the attack in ten of the eleven cases. ${ }^{95}$ In all eleven cases the man believed that his partner was having an affair. ${ }^{96}$ These findings appear to mirror the control motivations and emphasis on sexual jealousy characteristic of men identified as batterers, and are consistent

87. Showalter, et al., supra note 18.

88. Id. at 120 . While only 6 of the 11 men studied actually committed a homicide, the attacks by the remaining five were similar in type and motivation and thus considered "functionally equivalent" to a homicide for the purposes of the study.

89. Id. at 119.

90. Id. at 118-19.

91. Showalter et al., supra note 18 , at 139.

92. Id. at 125.

93. Id.

94. See supra notes 70-75 and accompanying text (obsession with the woman and "centrality" of the relationship are indicators of particularly dangerous men). Showalter further describes the men's relationships with the victims as one of "childish dependen[ce]." Showalter, supra note 18, at 127.

95. Showalter, supra note 18 , at 128.

96. Id. at 127. 
with battering literature's focus on the lethality of separation. Finally, Showalter states that only five of the eleven men reported having committed prior acts of violence against their partner. ${ }^{97}$ If true, this finding would obviously mitigate against a "battering" assessment. However, the accuracy of this self-reporting is thrown into serious question by the researcher's insensitivity to clues of prior violence. For example, in one of two stories used by Showalter as demonstrative of his "spousal-homicide syndrome", the homicide follows closely after the man is served with divorce papers. ${ }^{98}$ Showalter notes that the sheriff who delivered the papers had been instructed to stay at the residence until the man left, but failed to do so. ${ }^{99}$ It is a common practice in divorce actions in which physical violence is alleged to serve a restraining order with the complaint requiring that the abusing party leave the home immediately. The requirement that the sheriff remain on the scene until this was accomplished strongly suggests that the victim feared her husband's likely physical retaliation. Additionally, Showalter fails to include in his assessment of "prior acts of violence" a man's destruction of his wife's car in an effort to prevent her from leaving. ${ }^{100}$ Sensitivity to the literature on battering would have suggested that this was a violent act designed to frighten and control the woman by denying her a means of escape, ${ }^{101}$ an image in sharp contrast to the "abused" and beleaguered men Showalter describes.

\section{CONCLUSION}

In conclusion, homicide law divides sane individuals who intentionally kill into two major categories: those who premeditate murder and those who act in the heat of passion. Social stereotypes of wife-killing that characterize the killer as a previously non-violent man who "snapped" under pressure, roughly parallel the understandings which underlie heat-of-passion doctrine. However, this social stereotype is grossly inaccurate when applied to men who are identified as "batterers" and when applied to the general category of husband-wife killings. Violence perpetrated by abusive men is purposeful, not spontaneous; the majority of men who kill their wives have a documented history of violent assaults. Furthermore, one would expect to find empirical evidence

97. Id.

98. Id.

99. Showalter, supra note 18 , at 127.

100. Id. at 128.

101. See generally Mahoney, supra note 2, (importance of recognizing assaults on a woman's ability to separate). 
of wife-killers who fit the stereotype of the heat-of-passion killer in those reports of forensic psychiatrists whose job it is to aid defense counsel, yet these reports seem to confirm that men who kill and men who batter have remarkably similar personality traits and similar motivations. While further research is needed before we can determine whether or not the "impassioned" wife-killer exists, if he does exist, he is apparently part of a very small group of wife-killers.

\section{HEAT-OF-PASSION/ADULTERY DOCTRINE, AND THE JUSTIFICATIONS AND EXCUSES OF BATTERING MEN}

"[E]very act of human beings-even their crimes-says something." 102

When men kill their present or former wives or lovers, they bring excuses and justifications to law that reflect societal understandings of male rage and female provocation. These justifications and excuses resonate with and find expression in the heat-of-passion doctrine. James Ptacek notes that battering men, like others who are "called to account" for socially disapproved behavior, seek to "neutralize" their violence by engaging in excuses and justifications. ${ }^{103}$ Excuses are found in a man's denial of full responsibility for the violence; justifications in his accepting some responsibility for the violence, but "den[ying] or trivializ[ing] the wrongness of his violence."104

Four excuses and justifications made by abusive men particularly resonate with voluntary manslaughter doctrine: the claim of loss of control, the claim of provocation, the claim of emotional self defense, and the frequently intertwined charge that his partner has been, or desires to be, sexually unfaithful. This section will examine the congruence between these claims by batterers and certain aspects of voluntary manslaughter legal doctrine. Feminist literature and clinical research on battering have amply demonstrated that, when offered by abusive men, these claims are demonstrably false and rely on a belief system that validates male control of wives and lovers. This section will take this analysis one

102. Octavio Paz, Convergences: Essays on Art and Literature 40-41 (Helen Lane, trans., 1987).

103. Ptacek, supra note 3, at 141 (referring to the work of Scott \& Lyman).

104. Id. (emphasis added). Ptacek's definitions provide a rough parallel to the definitions of the terms found in criminal law. See Dressler, supra note 29, at 439. Excuse applies when the defendant does not deny the wrongness of his act, but argues that this state of mind makes him less blameworthy. The classic example of excuse would be not guilty by reason of insanity. Justification, on the other hand, argues that the act was not morally blameworthy. The classic example would be selfdefense. 
step further to show the mutually reinforcing connection between the socio-psychology of abusive men and the legal doctrine under which their violence is examined when they resort to homicide.

\section{A. The Excuse: Loss Of CONTROL}

\section{The Excuse Given by Battering Men}

Ptacek and others working with abusive men note that one of the most common excuses they give for their violence is that they were "out of control." 105 The validity of this excuse, however, is belied by at least three aspects of their behavior. First, the majority of abusive men are violent only with current or former wives or lovers or their children. ${ }^{106}$ Though they admit having similar feelings of frustration and rage in other settings, they do not respond violently in those settings. This is likely the result of differentially perceived risks as well as social learning that justifies violence against female partners (e.g., "If I hit my boss, I would get fired and maybe arrested; but my wife is supposed to do what I say ....").

The statements made in the following narrative provide an example of this kind of risk-weighing behavior which contradicts the loss of control excuse.

I found a note written by my wife... [that] said that she owed somebody $\$ 6$ for babysitting for her for twelve hours. I thought to myself "Where in the living hell could she have been gone for twelve hours?" My mind then turned to her stepping out with someone behind my back, so I called her. When she came in the room, I said, ..."Where in the hell where you for twelve hours? ...."

Then she started giving me some story about going shopping and going to the hairdresser's. . . I I said, "Don't hand me that bullshit; you're fucking around with someone." She said, "No, no, I'm not." Then I yelled, "You no-good tramp, dirty whore, you better tell me where in the hell you have been." She said, "You are acting like nothing but a bum: I'm not going to tell you anything." I thought to myself, "I'm going to beat the damn truth out of that no-good, rotten bitch." I started thinking about tying her up and beating her until she talked, but then I thought that if I went that far, she might leave me, so I

105. Adams, supra note 4; Ptacek, supra note 3, at 143 (56\% of the men gave this excuse); Sonkin \& Fazio, supra note 8.

106. See Ptacek, supra note 3, at 143 (finding $39 \%$ of his samples were violent only with wives or lovers; $33 \%$ with partners, children and mothers; only $28 \%$ were violent both within and outside of the family). 
dropped it. I was scared that if I did do it, then I would end up losing her. $^{107}$

Second, the statements made by abusive men directly contradict the loss of control excuse. For example, when asked why the violence wasn't more severe if they were "out of control," abusive men will frequently say that they did not want to hurt the woman seriously, ${ }^{108}$ suggesting at the very least, a measure of control over the degree of violence. In fact, while describing their violence as "out of control," many men admit to intending to harm or frighten their partner. ${ }^{109}$

Third, the accounts given by men who abuse are internally inconsistent with a loss of control account. The following explanation serves as a good example:

It's a condition of being out of control. She's going on and on ... you gotta get up and do something, you know. That's the way I felt, the way to do it was go over and try to shut her up physically. I'd lose my head. ${ }^{110}$

This man begins by appealing to a loss of control, but his second sentence suggests purposeful behavior (i.e., he had to "do something" to "shut her up"), while his closing sentence again returns to the loss of control theme. The second sentence discloses his bid for domination. Whether an abusive man really believes in his story of being out of control or is instead spinning a calculated lie-willing to tell any story which might diminish whatever retribution endangers him-is a difficult question and may depend on the abuser "type","11 the degree of self-awareness he possesses, and the degree to which an out-of-control story resonates with the family and community with which he identifies-including the degree to

107. KATZ, supra note 75 , at 41 .

108. Ptacek, supra note 3; see also Sonkin \& Fazio, supra note 8, at 228 ("[w] why he did not kill his victim or why he stopped his violence during a particular incident, he will usually reply, 'I wouldn't want to seriously hurt her or kill her' ").

109. Judith McFarlane et al., Response to Battering During Pregnancy: An Educational Program, Response to Victimization Women \& ChildRen, 1987, at 25; Ptacek, supra note 3, at 150. Neither do the manner of the attacks match the "out of control" description. For example, women are frequently beaten during pregnancy with the violence deliberately directed at the stomach area; blows are often aimed at unexposed parts of the body that make public detection less likely. Sonkin \& Fazio, supra note 8, at 229.

110. Ptacek, supra note 3, at 149.

111. EdWARd W. GONDOLF \& ElLEN R. Fisher, BatTered WOMEN as SuRvivors: AN AIternative to TREATING LeARNED Helplessness 59, $65-66$ (1988) (describing different typologies of batterers including the sociopathic batterer, the antisocial batterer, the chronic batterer, and the sporadic batterer). 
which they challenge or reinforce the story. ${ }^{112}$ One thing seems certain: the belief in the abuser's "out-of-controlness" reinforces his violence, offering him no encouragement to take personal responsibility for his violent conduct and reinforcing his victim-blaming thinking. As I will discuss in the next section, this victim-blaming in the form of an out-ofcontrol understanding of the battering receives much social supportcreating a reinforcing loop between the man's private perception of the etiology of his violence and the public's understanding of its etiology.

\section{The Reason Battering Men Give for Their Loss of Control: . Provocation and Victim-Blaming}

On some occasions she was the provoker. It didn't call for physical abuse. I was wrong in that. But it did call for something ... .you know, you're married for that long, if somebody gets antagonistic, you want to defend yourself. ${ }^{113}$

Clinicians working with abusive men note the frequency with which they engage in blaming the woman for their abusive behavior. ${ }^{114}$ This victim-blaming often takes the form of claiming that the woman provoked the attack. A woman's verbal aggression, for example, may be seen as the equivalent of a physical attack warranting physical retaliation. ${ }^{115}$ In addition to verbal aggression, abusive men claim to be provoked by their perception of the woman's inadequacy as a home-maker/ cook, by her "failure" to respond sexually or to behave in a deferential manner (e.g., "not knowing when to be quiet"), or because they believe her to be-or believe she desires to be-sexually unfaithful. ${ }^{116}$ Excuses and justifications have some variation in form, but as is apparent in the

112. See, e.g., Ellen Pence et al., In Our Best Interest: A Process for Personal and Social Change 33-34 (Minnesota Program Development, Inc., Duluth, Minn.) 1987 (describing the manner in which institutions reinforce a man's dominance and abuse).

113. Ptacek, supra note 3 , at 154 .

114. Adams, supra note 13 , at 186-87 (abusive man's description of his violence). Adams notes that:

The notion of provocation is insidious because what is really being said is that the woman has no real right to negotiate with her husband about issues such as how the money is spent, the time he spends away from home, the amount of assistance he might give with household tasks, or about her freedom to go to work, engage in her own hobbies or interests if such negotiations irritate or offend him.

115. Ptacek, supra note 3 , at 145.

116. Id. Needless to say, abusive men are not alone.in their willingness to blame their partners for the abuse. The frequency with which judges, police and other legal actors blame the victim of domestic assault for her abuse is well documented in both legal and activist work. See generally Laura Crites, A Judicial Guide to Understanding Wife Abuse, JuDGES' J., Summer 1985, at 5, 7 ("Gender bias can affect a judge in spouse abuse cases in the following three ways: (1) blaming the victim for not meeting her husband's needs and for provoking the violence; (2) tending to accept the husband's testimony over his wife's; and (3) identifying with the husband as victimized male."); 
following statements, they follow a standard pattern: they assume a norm for female/wifely behavior, assert that their partner has violated that norm, and thus blame her for provoking their violent behavior and/ or assert that she deserved to be punished.

My emotions just took over at that point. And I just went off at that point ... I shot [her lover]. And then I shot my wife. ${ }^{117}$

I was a good provider for my family and a hard worker. ... I told her if she stopped with the divorce, and that I would promise to act better ... but she wouldn't buy any of it. I got angrier and angrier. . . I I looked at her straight in the face and said, "Well, X, you better start thinking about those poor kids of ours." She said, "I don't care about them: I just want a divorce."

My hate for her exploded then, and I said, "You dirty, no-good bitch," and started pounding her in the face with my fist. She put her arms up and covered her face, so I ran and got my rifle and pointed it at her. I said, "Bitch, you better change your mind fast or I'm going to kill you." She looked up and said in a smart-ass way, "Go ahead then, shoot me." I got so mad and felt so much hate for her, that I just started shooting her again and again. ... ${ }^{118}$

Despite the obvious inconsistencies in the accounts given by abusive men, the description of battering as a result of "uncontrollable" rage has mental health adherents ${ }^{119}$ and clearly resonates with cultural understandings of the man who has been "pushed too far." 120 These men are using "socially approved vocabularies"121 to define their behavior in the most "understandable," and therefore sympathetic, light. The use of the familiar social constructs of female provocation and male victimization

Report of the New York Task Force on Women in the Courts: Domestic Violence, 15 FordHaM URD. L.J. 11, 32 (1986-87):

Police, court personinel and judges [who hear temporary restraining order hearings] too often presume that the victim provoked the incident, and that the assumed provocation excuses the violence. "Victim blaming is common .... Judges say to a woman when she walks in the courtroom, 'What did you do to provoke him?' It is incomprehensible to a judge that this woman could have been battered without some justifying action on her part."

117. People v. Thompkins, 230 Cal. Rptr. 516 (Ct. App. 1987) (reversed first-degree murder conviction, holding that the trial court erred in its instruction to the jury about the difference between premeditation and heat-of-passion. The defendant was separated from wife at the time.).

118. KATZ, supra note 75, at 33 (quoting from LonNie H. ATHENS, VIOLENT CRiminal AcTS AND ACTORS 46-48 (1980)).

119. See Ptacek, supra note 3 at 152 ("Like the abusers interviewed for this study, many clinicians also explicitly state that the [batterer's] violence represents 'uncontrollable rage' or 'uncontrollable aggression' [citations omitted] ... [and] clinicians frequently use explosion metaphors, such as 'violent eruption'; 'temper out-bursts'; or 'explosive rage' [citations omitted].").

120. See discussion infra notes $128-38$ and accompanying text (this cultural understanding is reflected in voluntary manslaughter heat of passion doctrine).

121. Ptacek, supra note 3, at 141. 
serve to make the batterer's quest for control over his partner invisible to those who are not looking for it.

When abusive men talk of their "loss of control," it cannot mean that they literally had no control-no volition. It is meant in the vernacular sense-a sense in which both justification and excuse are mingled: "This would make any reasonable man angry enough to choose to do violence." 122 The power of their stories is not in their logical consistency with the excuse of "loss of control," but rather in the way they resonate with a far more subtle and more culturally significant phenomenological definition of "out of control-ness."

\section{Voluntary Manslaughter Doctrine and "Loss of Control"}

The fundamental inquiry in determining the sufficiency of the defendant's mental state to constitute a killing voluntary manslaughter is whether the defendant's reason was, at the time of his act, disturbed or obscured by some passion ... to such an extent as would render ordinary persons of average disposition likely to act rashly or without due deliberation and reflection, and from passion rather than from judgment. ${ }^{123}$

The language used by many courts in describing a heat-of-passion killing suggests that the accused killed in an "uncontrollable rage,"124 that he acted out of "wild desperation."125 Criminal law theorists have struggled with just what is meant by "out of control" in the voluntary manslaughter context or what it means to say that the accused killed "under the sway of passion." If the accused really had no volition in the killing, then is it fair to punish him at all? The task of definition is made even more difficult by the additional requirement that the provocation be such that a "reasonable" person would also have been swayed by passion. Assuming that reasonable people are never moved so entirely by provocation as to kill, what does the reasonableness standard mean?

122. Mahoney suggests that one reason the power and control at the core of battering is so difficult to recognize in heterosexual assaults is due to the congruence between the expectations of battering men and those of society in general. This congruence makes the abuser's quest for control (of the woman) invisible in the stories men tell of being out of control (of themselves). Mahoney, supra note 2 , at 55 .

123. 17 Cal Jur 3d (Rev) Part 1, Criminal Law § 255 (1984).

124. "At trial defendant . . . claimed ... that he was provoked into killing her because of a sudden and uncontrollable rage so as to reduce the offense to one of voluntary manslaughter." People v. Berry, 556 P.2d 777, 779 (Cal. 1976).

125. "[D]efendant killed in wild desperation induced by [his lover's] long continued provocatory conduct." People v. Borchers, 325 P.2d 97, 102 (Cal. 1958). 
Joshua Dressler's approach to these questions is to suggest that voluntary manslaughter apply to those killings committed under provocation that would cause the "ordinarily law-abiding person ... . [to] lose self-control to the extent that he could not help but act violently, yet he would still have sufficient self-control ... [to] avoid using force likely to cause death or great bodily harm."126 If, however, the "ordinarily lawabiding person" could not have helped but to kill, then the defendant should be wholly excused. ${ }^{127}$ Dressler's focus on the accused's inability to refrain from violence-though he retains the ability to choose less deadly violence-is a close fit for the doctrine's focus on the "uncontrollable" nature of the killing. Similar to what is suggested by Dressler's analysis, the courts' use of the term "uncontrollable" does not mean the accused had no volition, but rather that the accused's ability to make choices was significantly impaired-though not rendered impossible.

Dressler's analysis shares with voluntary manslaughter/heat-of-passion doctrine three unexamined assumptions that underlie-and undercut-the understanding of these killings. First, "ordinary" people are provoked to violence. Second, this violence is an uncontrolled response, even if the degree of violence is not. Third, there is a certain inevitability to the leap from anger to violence: anger and violence seem to collapse, becoming the same thing.

Dressler's first assumption reflects the requirement under voluntary manslaughter doctrine that the defendant be provoked under circumstances that would similarly provoke a "reasonable" person. The premise of voluntary manslaughter doctrine's use of the reasonable person standard is that reasonable people are, under the right circumstances, provoked to violence; when a reasonable person's thinking is "disturbed by passion," violence is the response. Dressler's assumption ignores the manner in which social, cultural, and political definitions inform an individual's choice to resort to violence. The people with whom we are angry, the circumstances we define as anger-appropriate, and the way in which anger is expressed are socially constructed phenomena. ${ }^{128}$ More

126. Dressler, supra note 29 , at 439.

127. Id.

128. See generally Carol Tavris, ANger: The Misunderstood Emotion (1982) (the expression of anger and what it is that makes one angry is highly culture specific); Adams, supra note 13 at 183 ("What one becomes angry about and how one expresses that anger are greatly influenced by both culture and gender."); Donovan \& Wildman, supra note 47 (arguing that the "reasonable man standard" should be replaced with one that adjusts for differences in gender, culture, and situation); Note, supra note 47 (arguing that the ideal of a plural society requires that culture be taken into account in determining criminal punishment and that crimes motivated by "a sense of moral and social compulsion" are not readily deterred by criminal sanctions). 
importantly, Dressler's assumption completely misses the dimension that power and subordination play in defining the uses of violence. The extent to which one believes that one has options other than violence or, perhaps more to the point, the extent to which one believes that a violent response is morally justified in a given situation, necessarily reflects one's status vis-a-vis the provoker and one's expectations of what the provoker's "appropriate" behavior should have been. A decision to use violence necessarily reflects the balance of power between the two persons, as well as the actor's assessment as to whether his reference group would define the situation as calling for a violent response.

Dressler's and the doctrine's second assumption that under provoking circumstances, violence is an "uncontrolled" response-though the degree of violence may not be-provides a remarkable parallel for the quasi-out-of-control description abusive men give. Just as abusive men are not describing a complete lack of volition when they say they were "out of control," voluntary manslaughter doctrine does not really mean that the accused's behavior was "uncontrollable."

The quasi-lack-of-control phenomenon that emerges from voluntary manslaughter doctrine relies not only on the mental state of the accused-i.e., excuse doctrine, but also on a finding of moral blame on the part of the victim-i.e. quasi-justification. ${ }^{129}$ This is seen most clearly in the courts' rejection of claims that the behavior of a child or of a "resisting victim" can provide "adequate" provocation to render a killing voluntary manslaughter. ${ }^{130}$ The rejection of these claims relies on the concept of an "innocent" victim, the opposite of a "provoking," or blame-worthy victim. The doctrine, therefore, represents precisely the same mixture of victim-blame and "out of control-ness" that figures so prominently in the explanations of violence given by abusive men. By focusing on the behavior of the victim (was she provocative? was the provocation "adequate?") and on the anger of the accused (was he genuinely provoked?) voluntary manslaughter doctrine's application to wifekillings obscures the struggle for control which is at the heart of battering, just as that struggle is hidden in the accounts that abusive men give of their violence.

129. Ashworth, supra note 6.

130. See, e.g., People v. Balderas, 711 P.2d 480 (Cal. 1985); People v. Jackson, 618 P.2d 149 (Cal. 1980) ("[Where burglary victim awakened and began to scream,] [n]o case has ever suggested, ... that such predictable conduct by a resisting victim would constitute the kind of provocation sufficient to reduce a murder charge to voluntary manslaughter."); People v. Crews, 231 N.E.2d 451 (III. 1967) (behavior of two year old child cannot provide legally sufficient provocation to mitigate murder to manslaughter). 
Finally, Dressler assumes that violence, though not homicide, is a common response to certain provocative events-that rage leads inevitably to violence. This conflation of anger with violence is so imbedded in voluntary manslaughter doctrine as to appear common sensical. It is, therefore, not surprising that Dressler offers no empirical evidence to support this claim. ${ }^{131}$ It is, in fact, culture that mediates between anger and violence-that either encourages or discourages the transformation of anger into violence. ${ }^{132}$ Like provocation doctrine, Dressler does not ignore the social context that mediates between anger and violence: the need for the stimulus to be so significant that a "reasonable" person would have been provoked ${ }^{133}$ ties the event to its social context. The "reasonableness" requirement is designed to measure the legitimacy of the anger: if the event should not have provoked rage, than it is immaterial that the accused was actually provoked. This places at issue the legitimacy of the accused's rage, yet fails to question the fundamental assumption that conflates rage with violence. The truth is, the transition from anger to violence is no less culturally constructed than is the definition of what it is appropriate to get angry about. The result of collapsing anger with violence is to focus on the quality of the anger (e.g., was he passionately angry?) and miss the crucial question: what purpose did his anger serve? This collapse makes invisible the fact that "aggression is a strategy, not an instinct." 134

Voluntary manslaughter doctrine also treats anger as an inevitable result of provocative events and similarly conflates anger and violence. If adultery is the "paradigm" heat of passion event, anger is the paradigm heat of passion emotion. ${ }^{135}$ Traditionally and modernly in many jurisdictions, anger is the only recognized "heat-of-passion" emotion. For women accused of murdering husband's or lovers, the result has often been to exclude killings resulting from fear from the reach of voluntary manslaughter doctrine. ${ }^{136}$ However, the doctrine's anger model is equally as troubling when applied to men who kill their partners. The

131. Dressler, supra note 29.

132. See TAVRIS, supra note 128 and accompanying text.

133. See supra note 31 and accompanying text.

134. TAVRIS, supra note 128 , at $153-54$ (emphasis added).

135. See, e.g., People v. Sica, 245 P. 46 (Okla. 1926) (“'Anger' and 'passion' are interchangeable, and mean practically the same thing."); Dressler, supra note 29, at $427 \mathrm{n.61}$ ("[An]ger is the usual emotion alleged in provocation cases."); Taylor, supra note 6, at 1680-81 ("[R]age is still the paradigm emotion for heat of passion.").

136. Feminists have noted that while anger may describe the motivation of men who kill, it is a poor fit for women who are far more frequently motivated by fear or self-defense. Taylor, supra note 6. 
doctrine supports a belief in the inevitability of an angry response to provoking events and then conflates anger with violence, thus hiding the cultural leaps that take place when a man determines first, that his wife's behavior is worthy of his rage and second, when he translates that rage into violence. Both Dressler and the doctrine ignore this leap, providing another element of commonality between the social understanding abusive men carry regarding their violence and that of the legal doctrine. The combination supports an "out-of-control" understanding that serves to hide the power and control dynamics at the heart of the abuser's violence and to reinforce the belief that spousal homicide resulting from "passion" cannot be deterred. ${ }^{137}$ The research on deterrence, however, makes clear that many wife killers respond to criminal deterrence. ${ }^{138}$

\section{B. The JUSTIFICATION: Righteous RAGE ${ }^{139}$ AND MALE VICTIMHOOD}

Abusive men not only excuse their violence (e.g., "I was out of control"; "she provoked me"), they also justify it. When a man hits a woman because she used the wrong tone of voice, because she wasn't interested in having sex-“[y]ou don't tell me when to touch you"140

\section{The commentaries to the Model Penal CODE note:}

[Provocation doctrine] is a concession to human weakness and perhaps to non-deterrability, a recognition of the fact that one who kills in response to certain provoking events should be regarded as demonstrating a significantly different character deficiency than one who kills in their absence ... [Further,] [t]he underlying judgment [of common law provocation doctrine] is thus that some instances of intentional homicide may be as much attributable to the extraordinary nature of the situation as to the moral depravity of the actor.

Model Penal Code Commentaries to § 210. See also Ashworth, supra note 6, at 310-11 ("It is wise to be skeptical when deterrent arguments are applied to impulsive crimes, especially when the only direct deterrent effect would be limited to the difference between the penalty for murder and the probable sentence for manslaughter upon provocation.").

138. See supra note 79 and accompanying text; Patrick A. Langan \& Christopher A. Innes, Preventing Domestic Violence Against Women, BurEAu of Justice Statistics SPECIAI RePor'T (Aug. 1986). U.S. Department of Justice study found that a "woman was $41 \%$ less likely to be assaulted again by her spouse or ex-spouse when she called the police." Criminal justice intervention also serves a counter-ideological function because its message of personal accountability challenges the abuser's victim-blaming excuses and justifications. However, differing personality types as well as differing financial circumstances may influence the degree to which arrest deters. LAWRENCE W. Sherman et al., Policing Domestic Violence: Experiments and Dilemmás 17 (1992); Eve S. Buzawa \& Carl G. Buzawa, Domestic Violence: The Criminal Justice Response 89 (1991).

139. See KATZ, supra note 75 , at $12-15$ (this is a paraphrase of Katz' "righteous slaughter" term).

140. Smith v. State, 277 S.E.2d 678 (Ga. 1981). For a discussion of this case see Christine Littleton, Women's Experience and the Problem of Transition: Perspectives on Male Battering of Women, 1989 U. CHI. LegaI F. 23, 33 (1989) (discussing, in part, the discontinuity between battered women's experiences and the legal view of battered women). 
because of her poor housekeeping, ${ }^{141}$ because she's not a "good mother," or because she's sleeping with someone else, he is not only excusing the violence because he was "provoked," he is also voicing two interrelated forms of justification. The first rationale is that "she deserved it."142 This justification calls on a clear sense of moral "right"; the violence is motivated by retaliation. ${ }^{143}$ The second kind of justification is one of emotional self defense: the man had to protect himself. The latter claim occupies a continuum from "I deserve better"- - claim very close to the more obviously retaliatory "she deserved it" justification-to the other extreme in which the man portrays himself as the real victim, forced to protect himself from his partner's (emotional) violence. The two forms are at times distinct, at other times completely indistinguishable, and frequently, both forms of justification fold into concepts of provocation. ${ }^{144}$

\section{Retribution and Retaliätion: "The Bitch Deserved It Defense"145}

"I should just smack you for the lousy wife you've been."146

There is ample evidence that abusive men assault and sometimes kill their wives or lovers in what they consider to be justifiable retaliation. They are most likely to kill when she attempts to leave or in some other way defies their authority, and they are likely to grossly escalate their violence when she has the temerity to fight back. ${ }^{147}$ What abusive men characterize as "justifiable" is obviously not any form of justifiable homicide recognized by law. Criminal law generally defines a revenge killing as first degree murder. A retaliatory killing is antithetical to the doctrinal understanding of voluntary manslaughter-the assumption being that revenge killings are marked by "cool" calculation evidencing premeditation, and therefore cannot be "hot blooded" killings. ${ }^{148}$ The

141. Ptacek, supra note 3 , at 147.

142. See Goodman, supra note 28, at A15 (describing "the bitch deserved it defense").

143. "[The violence] was a way I could win. She would know that she had gone too far in asking something, in constantly probing, requiring me to answer. So that would let her know how hurt or angry I was feeling." Ptacek, supra note 3 , at 148.

144. See id. (much of what battering men describe as "provocative" echoes their justificatory claims in that both frequently focus on victim blaming related to their partner's failure to know when to concede to their (male) authority).

145. The term is borrowed from Goodman, supra note 28.

146. Ptacek supra note 3 , at 148.

147. Dobash \& Dobash, supra note 3, at 274.

148. See, e.g., People v. Martinez, 238 Cal. Rptr. 265 (Ct. App. 1987) (despite defendant's claim that he acted in an uncontrollable rage precipitated by finding his girlfriend having sex with another man, there was sufficient evidence of motive and planning to support a first degree murder conviction where defendant desired revenge and wished to punish his girlfriend); People v. Hyde, $212 \mathrm{Cal}$. Rptr. 440 (Ct. App. 1985) (trial court's refusal to give a voluntary manslaughter instruction was proper where defendant, charged with murder of his ex-girlfriend's boyfriend, masqueraded as a 
court's hostility to a straight forward retaliatory claim is no less so when the defendant is charged with killing his unfaithful wife or lover. ${ }^{149}$

However, a justification claim of sorts is built into the common law definition of provocation because "an individual is to some extent morally justified in making a punitive return against someone who intentionally causes him serious offense."150 Though voluntary manslaughter's mix of both excuse and justification doctrine are doctrinally illogical, ${ }^{151}$ Carol Tavris suggests that the doctrine makes cultural sense as an attempt to reconcile a conflict between "two equally powerful value systems": strong prohibitions against intentional individual acts of violence and "[a] great passion for revenge, retribution, and [the] defense of moral values." 152

This mixture of partial justification and excuse is also apparent in the explanations that abusive men give for their violence. In 1988, police officer Clarence Ratcliff gunned down his estranged wife, Judge Carol Irons. ${ }^{153}$ Ratcliff told the police officers who arrested him, "I just couldn't take the bitch anymore." Ratcliff was convicted of voluntary manslaughter, as well as attempted homicide for shooting at the two police officers who came to Irons' assistance. One juror explained the

police officer in order to kidnap the victim, thus demonstrating premeditation inconsistent with a heat of passion defense); People v. Cancino, 73 P.2d 1180 (Cal. 1937) (first degree murder conviction affirmed where defendant killed girlfriend after suspecting her of having an affair and waited outside her apartment in order to catch her. "[W] hile it is true that the abandonment of all sense of moral duty on the part of the unfortunate woman was exhibited in a shocking degree, the law will not justify or excuse the putting to death of such person unless in so doing it is necessary for the protection of the life or limb of the one who kills.").

149. See text accompanying note 148 .

150. Ashworth, supra note 6, at 307 (emphasis in the original). Voluntary manslaughter doctrine has long been understood to draw both from excuse and justification (or partial justification) doctrine. Dressler, supra note 29.

151. See Dressler, supra note 29 , at $434-44$ ("justifications and excuses are generally mutually exclusive"). Excuse doctrine looks to the state of mind of the accused to determine whether or not the accused may fairly be held accountable for the killing. Justification doctrine looks instead to the social harm of the killing-determining that, under the circumstances, the killing represents less social harm than would have resulted had the defendant not killed. Justification doctrine assumes that the killer had the capacity to choose whether or not to kill, but the circumstances so constrained his options as to justify his decision; excuse doctrine assumes that the killer had no such capacity to choose. Id. at 439.

152. TAVRIS, supra note 128 , at 60 ("[t]he law allows individuals to become angry enough to kill, but only if they kill in the service of society's dominant values, and only if they kill without premeditation or self-control-'in the heat of passion' "). See also Jeremy D. Weinstein, Note, Adultery, Law, and the State: A History, 38 Hastings L.J. 195 (1980) (suggesting that the doctrine's limitations failed to successfully coopt the "cuckold's" need for revenge).

153. Goodman, supra note 28. 
voluntary manslaughter verdict this way: "[e]verybody felt he was provoked by his wife to do this. First of all, she went out with other men. Then he was having trouble sexually and I imagine she rubbed that in to him. Then he went to his lawyer's office and found out she wouldn't agree to the settlement. All of that provoked him into doing it."154 Both the juror's and Ratcliff's understanding of provocation include elements of justification as well as excuse: he lost control and she deserved it.

\section{Male Victims and Female Tormentors: The Quasi-Self Defense Claim}

Voluntary manslaughter has long been understood to draw upon both justification and excuse doctrine. In fact, as discussed previously in this Article, the two nearly conflate in a provocation claim. However, what is not so readily apparent is that when men kill their wives or lovers, they frequently present a more deeply hidden quasi-self-defense claim. Even in situations of the most horrific violence, abusive men invoke self-defense language. ${ }^{155}$ They characterize themselves as the real victims and view their partner's self-protection measures as attacks that must be defended against. ${ }^{156}$ If the woman gets a restraining order, she's doing something to him. A woman's decision to separate is characterized as "abandonment"- a charged word implying she has treated her partner unjustly, maybe even abusively.

The result is that a woman who attempts to separate from an abusive man is entrapped in a web of the man's making, in which every

154. Id. at A15 (emphasis added). When the jury verdict became public, the trial judge's office was flooded with thousands of protest letters. The judge responded to the public outcry by sentencing Ratcliff to two life sentences for his assault on the police officers, in addition to 10 to 15 years for voluntary manslaughter. Id.

155. "[H]usbands are' more willing to count even severe acts of violence (e.g., choking, punching, beating someone up) as self-defense rather than violence. [References omitted.] Frequently, what abusers report as self-defense is in reality violent retaliation." Adams, supra note 4, at 13-14.

156. The following dialogue recorded in a court mandated group for abusive men serves to illustrate this point:

Facilitator: What changed for you, Bill, after you were put on probation?

Bill: It seems like she can say anything she wants now because she knows if I get mad, I'll end up in jail.

Frank: Yeah, they know they've got you over a barrel.

Facilitator: What do you mean "they've got you over a barrel?"

Bill: You know, she knows that the guy can go to jail. ... Sandy [my wife] says to me, "If you ever touch me, I'll call the cops and you'll go to jail." She uses it as a threat.

Facilitator: How is that a threat? She's telling you that if you assault her, she'll call the police and you will end up in jail. That doesn't sound like a threat, but a commitment to doing whatever she can to protect herself from getting hit again.

Bill: Well, yeah, but it's the tone of voice and all that. She uses it to get me. She knows I'm not going to hit her.

Pence \& Paymar, supra note 55, at 165. 
action she takes to protect herself threatens to reinforce his view that she's attacking him; thus, actions taken to increase her safety also have the potential to increase her danger. For example, many women attempt to leave an abusive relationship when the violence becomes severe or takes a sudden jump in severity. They leave to protect themselves and their children from the escalating violence. However, we also know that women are in the greatest danger of being killed when they separate or attempt to separate. ${ }^{157}$ Thus, a woman who attempts to leave is gambling: if she stays he may kill her, if not now, then later; if she leaves and he finds her, he may kill her because she left him.

The decision to take legal action is similarly fraught with danger. For example, getting a restraining order offers the potential benefit of sending a message that there are consequences to his violence which may result in diminished violence or none at all; a restraining order also makes it more likely that the police will intervene early-as opposed to too late. On the other hand, the abusive man may believe a restraining order to be an escalating move on the woman's part which serves to raise the stakes of the conflict. To the batterer, the restraining order is an attack which requires a counter-attack: "before I was just playing, but if you're going to do this, I'll get serious, too." The restraining order may also kill his hope of reconciliation which, in turn, increases his desperation and again raises the stakes in his mind-putting his very manhood on the line.

Jack Katz' description of the killer engaged in "righteous slaughter" 158 further demonstrates the conflation of justification and excuse in a provocation claim, as well as the way in which the two forms of justification-"she deserved it" and a quasi-self-defense claim-are intertwined. Katz theorizes that a person engaged in "righteous slaughter" is first responding to an act of humiliation. By turning his humiliation into rage, the attacker is able to transcend his feelings of humiliation. He can then transform rage into violence by viewing himself as a defender of "the [social] Good" (e.g., his role as husband, father, competent lover). Through the violent act, the attacker is able, at least for a moment, to recapture his social sense of self, a self that he believed to be threatened or annihilated by the humiliating event. ${ }^{159}$

157. Brisson, supra note 2 and accompanying text; Mahoney, supra note 2.

158. KATZ, supra note 75 , at $18,22-26$ (a theme of self-righteous anger runs through many of Katz's accounts, thus blurring the distinction between a claim of provocation and a claim of right).

159. Id. For example, Katz believes that the man who feels humiliated by his partner's infidelity feels that "cuckold" has come to define him-he is no longer in control of the public definition of who he is. He may transcend this humiliation through rage followed by violence, thus allowing 
Whether the killing Katz describes would fit the legal doctrinal understanding of "heat of passion" would depend largely on the fortuities of the jurisdiction the killer found himself in, the nature of the humiliating event, and its proximity in time to the killing. ${ }^{160}$ Regardless of these variables, however, a conception of provocation is clearly at the heart of Katz' description. Though the justificatory themes may be more apparent in Katz' description, the excusing image of a man pushed outside the boundaries of his self-control is also clearly present. The justificatory themes are evident in that the killer starts his trajectory from the point of a deep humiliation caused by the victim, hence the invocation of the partial-justificatory belief that the victim "deserved something." Additionally, the killer believes that he is engaged in a "righteous" act in defense of "the Good." From the killer's perspective, though clearly not necessarily from the law's, his act of killing is thus justifiable in the traditional sense-it is better that he killed than had he not killed. However, the righteous killer attacks not only to retaliate against the one who has harmed him; he attacks in order to undo the harm done to him. The act of violence restores his sense of self, transcends his feelings of deep humiliation, and thus becomes an act of selfprotection. ${ }^{161}$

himself to "recapture" his social self. Katz fails, however, to identify the gendered nature of his analysis. For example, he states that "humiliation always embodies an awareness of impotence," without noting that "impotence" is a term generally humiliating only for men. Id. at 24 .

160. Compare Commonwealth v. Coleman, 322 N.E.2d 407, 414 (Mass. 1975) ("[m]anslaughter in the "heat of passion' sense is not plausible because there was time for cooling off") with People v. Berry, 556 P.2d 777 (Cal. 1976) (whether or not the time elapsed between the provoking event and the killing was sufficient for a reasonable person's passion to have cooled is a jury question) and GA. CODE ANN. § 16-5-2 (Michie 1984 \& Supp. 1986) (the jury "in all cases shall be the judge" of whether or not an interval of time between the provocatory act and the killing was sufficient "for the voice of reason and humanity to be heard ..."); compare State v. Guebara, 696 P.2d 381, 386 (Kan. 1985) ("Mere words or gestures, however insulting, do not constitute adequate provocation. . . .") with People v. Wickersham, 650 P.2d 311, 321 (Cal: 1982) (quoting People v. Berry, 556 P.2d 777 (Cal. 1976) (" "there is no specific type of provocation required . . . and verbal provocation may be sufficient" "); compare State v. Gounagias, 153 P. 9 (Wash. 1915) (rejecting cumulative provocation argument, holding that as a matter of law an event that preceded the killing by two weeks could no longer provide adequate provocation) with People v. Borchers, 325 P.2d 97 (Cal. 1958) (sufficient provocation may be the result of a "series of events over a considerable period of time").

161. KATZ, supra note 75, at 26-31 (humiliation is to feel "morally assault[ed]," in contrast to the feeling of rage which "turn[s] the structure of . . . humiliation on its head", while humiliation makes the person feel "small," rage "proceeds in an upward direction." Rage, therefore, transforms humiliation and serves to avenge and protect the humiliated person from further humiliation or annihilation.) This reassertion of himself as the one in control is, of course, predicated on sexist constructions of "male" and "female." It is his "maleness" which is threatened and must be defended. "[With justifications], [a]s in the example of 'provocation', there is a theme of self-righteousness about the violence. ... [I]t is a sense that the privileges of male entitlement have been unjustly denied." Ptacek, supra note 3 , at 148. 
The story of male emotional victimization can be found wherever men physically abuse women. For example, Lynne Henderson demonstrates the way in which the cultural story of heterosexuality, which has informed society's and the law's treatment of rape, relies largely on a male innocence/female guilt paradigm: "an unexamined belief that men are not morally responsible for their heterosexual conduct, while females are morally responsible both for their conduct and for the conduct of males." 162 Henderson notes that in this version of the story of heterosexuality, "women are seductive and have the power, like the Sirens, to drive men 'wild,' to lose control, and therefore not be responsible," 163 much like the story of male "out of control" rage and female provocation in the "battering" context. ${ }^{164}$ When an abusive man describes his violence as a result of his partner's conduct which "drove him crazy" he is invoking the same meta-story of victimized male/female tormentor. The male innocence/female guilt story hidden within an adultery provocation claim is not only about the man pushed "out of control" by a woman; if a woman is "driving him wild," he must protect himself. The irony in an abuser's provocation claim is that the woman's behavior that caused the man to "lose control" is the same behavior that provides the justification for his reassertion of control (of her).

Abusive men frequently equate a woman's verbal aggression with their own physical violence, ${ }^{165}$ as though there is no real difference between words and fists. Defiant, angry, rejecting, belittling, abandoning or merely disagreeing words warrant a violent assault.

162. Lynne Henderson, Rape and Responsibility, 11(1,2) LaW \& PHIL. 127 (1992). See also State v. Thornton, 730 S.W.2d 309 (Tenn. 1987).

163. Henderson, supra note 162 , at 5 .

164. See discussion supra notes 113-22 and accompanying text. Of course, distinguishing the "battering context" from the "rape context" is quite artificial. The abuse that abusive men visit upon wives and lovers, frequently includes rape. See generally DiANA E.H. RuSSELL, RAPE IN MARRIAGE (1982) (discusses both the frequency of rape in marriage and its correlation with other physical abuse).

165. See Ptacek, supra note 3, at 152; R. Emerson Dobash \& Russell Dobash, Violence Against Wives: A CaSe Against the Patriarchy 133 (1979) (Ptacek notes that the equation of verbal aggression with physical assault trivializes the violence and implies that battering is caused by "nagging," which sociologists Dobash and Dobash redefine as "continued discussion once the husband has made up his mind."); Daniel G. Saunders, Wife Abuse, Husband Abuse, or Mutual Combat? A Feminist Perspective on the Empirical Findings, in Feminist PersPectives ON Wife ABUSE, supra note 3, at 90, 100 ("Men tend to label violent responses to verbal abuse as 'selfdefense'.... The men are defending their self-image rather than defending themselves from physical harm. Saving face is a particularly strong motive when the woman is, or suspected to be, sexually unfaithful.") 
Abusive men are not alone in equating (female) verbal aggression with (male) physical aggression. ${ }^{166}$ The belief is underscored by the (mistaken) belief that women have superior verbal skills against which men cannot defend themselves. ${ }^{167}$ Clinicians assume that men cannot verbally communicate their needs and feelings and that abusive men are even less able to do so. Clinical attention, therefore, has been directed at increasing the verbal skills of abusive men. ${ }^{168}$ This focus has been sharply criticized both for its failure to recognize the power and control dynamics which underlie abusive behavior and for the inaccuracy of its fundamental tenet: the truth is that abusive men are frequently extremely adept at verbal expression. ${ }^{169}$ Abusive men, nonetheless, benefit from this social conception of the hapless man who must defend against a nagging, shrewish woman who torments him with words.

The belief that men are emotionally victimized by female tormentors is evidenced by social beliefs that equate (female) verbal aggression with (male) physical retaliation. This belief in male victimhood is, in turn, reflected in the view that men who abuse do so in response to a woman's "provocative" behavior or to protect themselves from a woman's vicious verbal assaults.

When freed from the legal definition of justification, it becomes apparent that the explanations abusive men give to justify their violence resonate with portions of voluntary manslaughter doctrine. This is most apparent in the manner in which voluntary manslaughter doctrine draws upon justification doctrine: someone who engages in serious provocation must expect some form of retribution. However, when the defendant is accused of killing his wife or lover, the quasi-self defense claim plays a more critical role than it does in other "provocation" cases. Within adultery provocation doctrine, the "victimized male" perspective is expressed

166. For example, Jack Katz appears to equate a woman's "ridicule" of a man's virility to a man's physical assault. KATZ, supra note 75, at 37-38, 48 (describing a man's physical assault resulting in a black eye as a "sacrificial marking" the equivalent to a woman's verbal aggression: "A woman can distinctively mark a man by ridiculing his virility and, whether or not the woman works, by shaming him for failing to uphold the traditional, symbolic male responsibility for the economic status of the household.").

167. See, e.g., Gloria Steinem, OUtrageous Acts AND Everyday Rebellions 201-03 (1983) (citing research finding that men talk more than women).

168. See generally Adams, supra note 13 (describing therapeutic models for men who batter that teach communication skills).

169. Adams, supra note 13, at 183 (quoting Ellen Pence, The Justice System's Response to Domestic Assault Cases: A Guide to Policy Development (1984): "abusive men are already "experts at venting their anger' and ... they often justify their angry outbursts on the grounds of being honest about their feelings.") 
in two ways: the equation of adultery with a physical assault, and the adultery exception to common law "words alone" doctrine.

\section{Voluntary Manslaughter Doctrine and Justification: Adultery is an Assault and Words are Weapons}

As noted previously, adultery provides the only traditional category of adequate provocation that does not involve an assault or battery. ${ }^{170}$ That this anomaly has so long been ignored demonstrates the power of the social construction of female adultery as an assault on the male partner. ${ }^{171}$ Similarly, voluntary manslaughter doctrine provides a rough parallel for the abusive man's view that abandonment or defiance of his authority is as an assault requiring his self-defense or retaliation. This parallel between adultery provocation doctrine and the justifications abusive men offer can be seen in the common law doctrine of those jurisdictions which provide an adultery exception to the general "words alone" rule. While the traditional rule is that, "mere words or gestures, however insulting, abusive, opprobrious, or indecent" cannot constitute adequate provocation sufficient to mitigate what would otherwise be murder to the crime of voluntary manslaughter, ${ }^{172}$ a number of common law jurisdictions recognize an exception in the context of a wife's confession of adultery. ${ }^{173}$ Again, of those exceptions to the "words alone" rule, adultery is the only major category not to involve an assault or threat of assault. ${ }^{174}$

170. Supra note 7 and accompanying text.

171. I am indebted to Mark Kelman who first suggested to me that the interesting question is "what makes adultery like a physical assault?"

172. WhaRTON's CRIMINAL LAW, supra note 31, at 244.

173. See Perkins \& BoYCE, supra note 5 , at 94.

Under the sound rule, recognized by most courts, informational words are placed upon a different footing than insulting words. The sound theory is that it is the fact, or alleged fact, which really constitutes the adequate provocation, but the sudden disclosure of the fact may have the same effect as if it had just happened. Thus an intentional killing may be manslaughter only if the deceased had just told the slayer that he had . . . committed adultery with her....

Id. Strickland v. State, 357 S.E.2d 85 (Ga. 1987) (where one spouse taunts the other spouse with prior acts of adultery, that is sufficient provocation to reduce a homicide from murder to voluntary manslaughter because it is the adulterous conduct, not the words themselves "which engender the sudden violence and irresistible passion upon which the voluntary manslaughter offense is predicated."). See also Commonwealth v. Greene, 362 N.E.2d 910, 913 (Mass. 1977); Commonwealth v. Berry, 336 A.2d $262(\mathrm{~Pa}$. 1975). The exception has always had significant limitations: the attack must follow the confession closely in time and the defendant who already knew of the adultery is ineligible to make the claim because the provocation was not "sudden". Of course, significant indications of premeditation may also prevent the question of provocation from reaching a jury. See, e.g., People v. Martinez, 238 Cal. Rptr. 265 (Ct. App. 1987) (first degree murder conviction affirmed where defendant had repeatedly threatened to kill victim if he caught her with another man).

174. See 2 ALR 1292, 1294 (1965) (noting that the following are excluded from the "words alone" rule: (a) threats; (b) conduct presenting a mixed issue of threat and insult where it is unclear 


\section{Heat of Passion Killers and Domestic Killers Are "Unlikely Recidivists"}

Many legal scholars defend voluntary manslaughter's relatively light punishment by arguing that the heat of passion killer is unlikely to commit future acts of violence. ${ }^{175}$ The argument is, presumably, that since the killer acted as a result of particularly egregious circumstances, and particularly egregious circumstance are, by their nature, infrequent occurrences, the killer poses little future threat to society. When a man kills his wife or lover, this general belief regarding "heat of passion" killers is sometimes reinforced by similar beliefs regarding wife-killings. For example, C. Robert Showalter argues that the men in his study are "clearly differentiate[d] . . . from the stereotypical murderer [because] the person who kills a spouse is a most unlikely recidivist."176 Though Showalter doesn't clearly explain this conclusion, it appears to rest on his assessment that the assaults were the result of "the psychological intensity of the provocation, the peculiar vulnerability of the offender, and the distinct aberration of mental functioning which unleashes the murderous aggression."177 Showalter's assumption that the wife-killer who kills under the stress of "intense provocation" is unlikely to kill again is rendered suspect by the degree to which Showalter's men appear to overlap with the population of "battering" men. As discussed previously in this article, men who are abusive in one relationship are likely to abuse again in the next relationship. ${ }^{178}$ While likelihood of future abusive behavior is enough to make Showalter's non-recidivist assumption problematic, in

which provoked the killing; (c) insults accompanied by some type of physical battery; (d) an admission of adultery by a wife to her husband, or words to the effect that she intended to commit adultery).

175. It is not uncommon for a commentator to invoke in the same article both major rationales for heat of passion doctrine: i.e., these killings are not amenable to deterrence and these killers are unlikely recidivists. See, e.g., Note, supra note 22 , at 1038 (the author notes that "[i]t might also be suggested that if such homicides are committed by excitable people consumed by the heat of passion, it is unlikely that such individuals could or would stop to consider the legal consequences of their act before they engage in its commission," but ends the article by stating, "[t]he way is open for the courts to discontinue the practice of sending those guilty of manslaughter to institutions under the pretense that they require as long a time to become rehabilitated as those who are guilty of murder").

176. Showalter et al., supra note 18, at 139 (emphasis added). See also Buzawa \& BuzawA, supra note 138, at 56-57 ("Court personnel tend to believe that defendants in a relationship case may be influenced by relationship itself. Thus they are perceived as not being a 'hard case' and much less likely to be recidivistic than those responsible for violence, property loss, theft against strangers ....").

177. Id. Showalter bemoans the common law's inadequacy, at recognizing the situation of this kind of killer because "[the law] is oblivious to the victim's role in his or her own demise" in what Showalter earlier described as a "classic illustration of "victim-precipitated homicide[." Id. at 118.

178. See supra note 52 and accompanying text. 
fact, anecdotal evidence suggests that men who kill wives or lovers are not only likely to beat future partners, but may be more likely to kill again, as well. ${ }^{179}$

Despite the evidence to the contrary, Showalter's view of wife-killing predominates in much of criminal law practice and jurisprudence with disastrous results. The case of Garcia v. Superior Court, ${ }^{180}$ brought by the children of murder victim, Grace Morales, provides an example. Grace, who had already suffered severe abuse at the hands of her exboyfriend, parolee Napoleon Johnson, was subsequently abducted and killed by him. Despite Johnson's numerous threats to kill Grace in the presence of his parole officer, the officer refused to move to revoke Johnson's parole and actually encouraged Grace to reconcile with Johnson, telling her that Johnson posed no threat to her or to her children. ${ }^{181}$ While the parole officer failed to heed many warning signs, one warning sign is entirely ignored by the court, as well: Johnson's parole was from a homicide conviction for killing his first wife. ${ }^{182}$ In fact, Johnson's status as one who had already killed an intimate partner should have alerted his parole officer to the possibility that he might kill a woman again. ${ }^{183}$ Instead, the parole officer failed to tell Grace the nature of Johnson's prior conviction. ${ }^{184}$

179. See, eg., infra notes 180-84 (discussion of Garcia, 789 P.2d 960 (Cal. 1990)); see infra note 212 (Berry, accused of killing his wife, had prior assault conviction for stabbing former wife); Mike McDevitt, Judge OKs Evidence in Homicide, Peninsula TMmes TrIBUNE, Apr. 18, 1990, at B5 (man accused of strangling two different women with whom he had romantic relationships); San Diego County Digest: Local News in Brief: Escondido, L.A. Times, Dec. 6, 1988, at M3 (man charged with murdering his girlfriend had prior manslaughter conviction for killing his first wife); Man Sent to Prison, supra note 28 (man wanted for killing wife is turned in by girlfriend who feared for her own safety); Arnold, supra note 28 (in prosecution of man convicted of voluntary manslaughter for killing girlfriend the court disallowed evidence that defendant repeatedly beat a former girlfriend).

180. Garcia v. Superior Court, 789 P.2d 960 (Cal. 1990).

181. Id. at 962 (The probation officer told Grace that she "[didn't] have anything to worry about" and that Johnson was still in love with her and "repeatedly asked her if she really wanted to end the relationship.").

182. The opinion's only reference to this fact is its reference to Johnson as "a convicted murderer on parole." Id. at 961 . The relevance of this murderous history is completely missed in the court's assessment of the parole officer's culpability for making false statements to Grace regarding Johnson's non-dangerousness. Id. at 964.

183. Mahoney suggests that the recidivism of "separation assaults" requires further examination, but is suggested in cases such as Garcia. Telephone Interview with Martha Mahoney, Professor of Law at University of Miami Law School (Jan. 1993); see also, Mahoney, supra note 2, at 77 ("The parole officer misrepresented Johnson's danger to Morales with respect to the very issue of measures regarding separation.") (emphasis in original).

184. Garcia, 789 P.2d at 962 . State law prevented the parole officer from giving Grace information regarding Johnson's criminal record. Id. at 963 n.2. However, the officer also stated that Johnson's crime "was not the type which would indicate that Johnson represented a danger to [Morales's] 
Psychological theories of violence against wives or lovers that ascribe some role in the causation or maintenance of the battering to the woman/victim may further underscore the belief in the exceptionality of the accused's violence. These theories suggest that the woman caused the violence through her provocative behavior; ${ }^{185}$ or maintained the violence by "staying" when she should have left, thus "reinforcing" the man's abusive behavior; ${ }^{186}$ or, put with more sophistication, maintained the violence through her role in an interactive "system" that operated, perhaps unconsciously, to sustain the man's violent behavior. ${ }^{187}$ The influence in the courtroom and on popular culture of such "interactionist" or "systems" psychological theories cannot be overstated. ${ }^{188}$ This rationale for voluntary manslaughter doctrine's lesser penalty parallels a social understanding of domestic violence: heat-of-passion killers act as a result of a peculiar set of circumstances and are therefore unlikely to kill again; battering results from the dynamics of a particular relationship or in

children." Id. at 962. As Mahoney notes, this statement was a patent falsehood: "[T] he possibility of [Grace's] murder and the possibility of harm to themselves in the course of a murderous attack were 'danger' shown by Johnson's prior conviction." Mahoney, supre note 2, at 77 n.345.

185. See infra discussion of People v. Berry (psychiatrist argued that victim precipitated her own death by taunting and sexually teasing the accused).

186. See, eg., Mildred Daley Pagelow, Woman-Battering: Victims and Their EXPERIENCES (1981) ("if [the battering] behavior appears to be accepted by his spouse because of lack of negative feedback, he is most likely to continue [to batter]."); see also Mahoney, supra note 2, at 31-32 (while Pagelow's analysis identifies power and control issues in battering, it then "obscures them again by indirectly holding the woman responsible for the batterer's continued control efforts[.]").

187. Bograd, supra note 19, at 562 (Systems models typically see the family as a structural system unit in which relationships are "complementary" and violence is used to reestablish "homeostasis" when that complementariness is disturbed.) See also Adams, supra note 3, at 13-14 ("[a]ccording to the interactionist perspective, battering is not characterized as one partner attempting to control or dominate the other but by the couple's combined communicational deficits and the attempts of both partners to coerce and otherwise incite the other"). Adams quotes the following interactionist account of battering:

Consort battering [sic] fits very well into the model of coercive exchanges building up to aggression by one party and forced submission by the other partner.... It hardly matters whether the husband or the wife initiated the first unpleasant event, for they both respond by trying to control the other person via escalation of negative remarks and threats, until one of them loses control and resorts to physical force to make the other one submit.

Id. (quoting Jeanne P. Deschner, The Hitting Habit: ANger Control for Battering COUPLES (1984)).

188. For example, this view is demonstrated by the reluctance of civil judges to deem wife abuse relevant to the determination of custody. Not only have women been blamed for their ex-partner's abuse, but judges have been extremely reluctant to examine the issue of whether or not the abuser is likely to re-abuse in subsequent relationships with women. The belief that the abuse is the result of the particular dynamics of a given relationship, if not the result of the behavior of a particular woman, have clearly influenced this judicial reluctance. See generally, Crites \& Coker, supra note 10. 
response to a particular woman and therefore, batterers are unlikely to abuse in subsequent relationships. ${ }^{189}$

\section{PEOPLE V. BERRY}

Appellate court opinions are likely to be particularly skewed in domestic heat-of-passion cases and there is little or no data regarding the sentencing disposition of men who kill wives and lovers. ${ }^{190}$ Therefore, an analysis of trial court data is necessary in order to begin to determine the extent to which a "domestic violence discount"191 operates to produce reduced sentences for men who kill wives or lovers. ${ }^{192}$ Trial court proceedings can provide data regarding the real world effect of the congruence between the excuses and justifications of abusive men and their doctrinal counterparts in voluntary manslaughter doctrine. The remainder of this article will analyze an entire case-from the accused's police confession, to the trial transcript, to the final California Supreme Court opinion-in order to illustrate the central points of this Article's analysis.

189. In reality, studies that have attempted to identify the personality type of women likely to be battered have failed. See generally MARY ANN DUTTON, EMPOWERING AND HEALING THE BATTERED WOMAN: A MODEL FOR ASSESSMENT AND INTERVENTION 3-12 (1992) (recent studies focus on the effects of wife abuse on a woman's psychological state, rather than on an assumed psychological pre-disposition to be battered); Pagelow, supra note 186, at 168 (contrary to the popular understanding, only about one-fourth of the battered women studied witnessed spouse abuse in their home of origin, compared to half of the abusive men studied); Stacey \& Shupe, supra note 60 , at 55 (contrary to popular belief, nearly half of the women entering the shelter ranked high in selfesteem).

190. See supra notes $25-28$ and accompanying text.

191. Elizabeth Rapaport's study of capital murder convictions suggests that there is a "domestic [violence] discount" which serves to view domestic violence cases, particularly those in which a man kills in response to his partner's threat to leave him, as less serious. Elizabeth Rapaport, When is Domestic Homicide a Capital Crime?: Gender Differences in America's Death Rows in the PostFurman Era 25, presentation for Law \& Society Meeting (May 28-31, 1992) (on file with author). Rapaport notes that "[i]t is fair to conclude-regardless of whether one would wish to see domestic violence more heavily sanctioned-that it is not a wall between premeditated and unpremeditated murder that shelters domestic killers from capital responsibility but rather our cultural ranking of domestic violence as less morally serious than predatory crime[s] [which are more likely to result in a death sentence]." Id. at 23 (emphasis added).

192. Phyllis Goldfarb notes that the appellate court focus of critical legal studies scholars limits the accuracy of their resulting social theory. Phyllis Goldfarb, Beyond Cut Flowers: Developing a Clinical Perspective on Critical Legal Theory, 43 Hastings L.J. 717, 731 (1992). This article attempts to enlarge the scope of its analysis by addressing the critical question: How does this all play out at trial? 


\section{A. THE BACKGROUND IN BERRY}

The case of People v. Berry ${ }^{193}$ appears in many criminal law textbooks as well as legal treatises, generally for the proposition that the question of "cooling off" is a jury question. ${ }^{194}$ The California Supreme Court in Berry overturned the defendant's first degree murder conviction for the killing of his wife, Rachel Pessah. At trial, Berry testified ${ }^{195}$ that three days after their wedding, his wife Rachel left him to visit her home country of Israel. Upon her return, she informed him that she had a lover in Israel named Yacob and intended to divorce Berry in order to be with him. Over the course of the next several days, Rachel alternately expressed a desire to have sex with Berry and a contrary desire to "save herself" for Yacob. Berry choked Rachel at least two times prior to killing her-the second time strangling her severely enough to render her unconscious. Following this second assault, Berry called a cab to take Rachel to the hospital and he moved in with friends. Subsequently, Rachel filed a warrant for Berry's arrest. On the same day that Berry learned of the warrant, he let himself into the empty apartment where Rachel was still living and waited 20 hours for her to return home. The opinion describes what happened next:

Upon seeing [Berry] there, [Rachel] said,"I suppose you have come here to kill me." [Berry] responded, "yes," changed his response to "no," and then again to "yes," and finally stated "I have really come to talk to you." Rachel began screaming . . . [and] finally defendant strangled her with a telephone cord. ${ }^{196}$

At trial the court refused to give a jury instruction on voluntary manslaughter, ruling that as a matter of law the 20 hour wait in the apartment was a sufficient "cooling off" period to have allowed a reasonable man's passion to cool. ${ }^{197}$ The California Supreme Court remanded the case, holding that Berry had adequately demonstrated provocation to warrant a jury instruction on voluntary manslaughter and that having demonstrated a "long course of provocatory conduct" which "reached

193. People v. Berry, 556 P.2d 777 (Cal. 1976). This analysis relies not only on the California Supreme Court opinion, but also the trial transcript and the transcript of Berry's confession to the police. People v. Albert Joseph Berry, No. 88-2b Crim. No. 19194 (Superior Ct. of the City and County of San Francisco, 1974), Trial Transcript and Transcript of Statement of Albert Joseph Berry taken at Homicide Detail, Hall of Justice, San Francisco, August 1, 1974.

194. See Kaplan \& WeISBERG, supra note 47.

195. Berry offered no corroboration of his account of the facts other than the psychiatrist's professional judgment that he was not lying. Berry, 556 P.2d at 779 n.3.

196. Id. at 780.

197. Id. at 780. 
its final culmination . . . when Rachel began screaming,"198 the question of "cooling off" should go to the jury. The Berry opinion places the decision in line with earlier California case law finding that a series of provocative behaviors may provide legally adequate provocation to mitigate murder to manslaughter. ${ }^{199}$

At his trial, Berry offered only two defense witnesses: himself and a psychiatrist, Dr. Martin Blinder. ${ }^{200}$ Dr. Blinder testified that

[Rachel] was a depressed, suicidally inclined girl [sic] and ... this suicidal impulse led her to involve herself even more deeply in a dangerous situation with defendant. She did this by sexually arousing him and taunting him into jealous rages in an unconscious desire to provoke him into killing her and thus consummating her desire for suicide. ${ }^{201}$

The defense needed Blinder's testimony for two different, but equally critical, reasons. First, the fact that Berry had a prior conviction for stabbing and injuring his second wife had already been ruled admissible. ${ }^{202}$ Blinder's testimony was required to neutralize this damaging fact, but, in fact, Blinder went one step better by explaining that Berry's past violence resulted from his repeated emotional victimization at the hands of women. ${ }^{203}$ Second, Blinder's testimony was needed most obviously in order to cast the killing as a heat of passion killing and, in particular, to explain the 20-hour wait in Rachel's apartment as a result of cumulative passion and not premeditation and lying-in-wait. The result was psychiatric testimony that brilliantly-if tautologically-turned facts about Berry that suggested the antithesis to a "heat of passion killer"-i.e., a proclivity for violence, a history of serious prior assaults on the victim

198. Id. at 781 .

199. See, e.g., People v. Borchers, 325 P.2d 97 (Cal. 1958) (upholding trial court's decision to reduce a second degree murder conviction to one for voluntary manslaughter). The court in Borchers held that "the trial judge could well have concluded that defendant was roused to a heat of 'passion' by a series of events over a considerable period of time: [the victim's] infidelity, her statements that she wished she were dead, her attempt to jump from the car [they were riding in on the night of the homicide], her repeated urging that defendant shoot her, Tony [her quasi-adopted son], and himself on the night of the homicide, and her taunt, "are you chicken." Id. at 102. The Borchers court concluded that "defendant killed in wild desperation induced by [the victim's] long continued provocatory conduct." Id.

200. $556 \mathrm{P} .2 \mathrm{~d}$ at $780 \mathrm{n} .3$.

201. Id. at 779.

202. The indictment alleged this prior felony conviction, but on appeal to the Supreme Court the Attorney General conceded that the trial court's acceptance of Berry's admission was improper. Id. at $778 \mathrm{n} .2$.

203. Blinder's testimony also, presumably, went to Berry's diminished capacity defense. The trial court's refusal to instruct on voluntary manslaughter in the context of a diminished capacity defense was upheld on appeal. Id. at 781-82. 
identical in kind to the fatal assault, Berry's stabbing of his ex-wife under remarkably similar circumstances, and a psychological profile fitting that of an abuser-into evidence of Berry's increasing provocation as the result of Rachel's relentless "taunting."

\section{B. "INNOCENT" V. "IN COLD BLOOD" TURNED ON ITS HEAD}

\section{Berry's Defense: A Propensity to Batter Women}

In essence, Berry's defense was that he was the sort of man who abused women - but the twist was Blinder's psychiatric explanation that Berry's violence was a result of his choosing women who enraged him and provoked him to violence. The fact that Berry had a prior conviction for assaulting his ex-wife with a butcher knife, that in past relationships with other women he had destroyed their property, forcing former girlfriends to "put him out of the house, locking the door,"204 indicated to Blinder the personality of the women with whom Berry involved himself, more than it demonstrated Berry's dangerous and abusive nature. Blinder testified that these women "offer[ed] him the promise of comfort but ultimately deliver[ed] . . . emotional pain."20s Yet Blinder's testimony provides a classic portrait of an abuser. Berry was most dangerous when women threatened to leave him. ${ }^{206}$ Berry was "emotionally dependent" on wives and girlfriends; he threatened physical violence in order to control women; ${ }^{207}$ he destroyed women's property; ${ }^{208}$ and he had a

204. Trial Transcript at 144, Berry, No. 88-2b Crim. No. 19194.

205. Id. at 145.

206. For example, Dr. Blinder acknowledges that Berry's act of homicide was likely in response to Rachel's attempt to leave him, id. at 177, and that Berry's knife assault on his second wife was shortly after she threatened to leave him, id. at 143 , and that Berry destroyed the stereo of a girl friend when she threatened to leave him, id. at 145.

Q. Is it also reasonable to say that he killed because she was going to leave him, is that correct?

A. You are putting it rather badly, but in a sense that is accurate.

Id. at 177. See also Mahoney, supra note 2, at 74 (describing Berry as a "hidden separation assault" case).

207. Trial Transcript at 144, Berry, No. 88-2b, Crim. No. 19194.

208. An expert likely would have testified that Berry was an example of a batterer. See, e.g., Sonkin \& Fazio, supra note 8, at 223 (describing abusive men as dependent on their female partners); Don Dutton et al., Severe Wife Battering as Deindividuated Violence, 7 Victimology 13, 17 (1982) (describing battering men as typically emotionally isolated with an "exaggerated dependance on the female [partner]." The authors further note that "for battering males[,] acute anxiety accompanies perceived rapid changes in socio-emotional distance (or intimacy) within relationships."); Dobash \& Dobash, supra note 3 (describing the way in which abusive men "set up" situations in which they can justify feeling "provoked"); Dutton et al., supra note 208, at 27 (describing destruction of property as a frequent example of both threatening behavior and emotional abuse). 
history of violent relationships with wives and lovers. ${ }^{209}$ The Supreme Court's opinion read Dr. Blinder's testimony to focus narrowly on the effect of Rachel's "provocative" behavior on Berry's mental state. ${ }^{210} \mathrm{Dr}$. Blinder's testimony, however, refers to a cumulative rage resulting from the provocation of all the women in Berry's entire life:211

Q: ... How would you characterize [Berry's] state of mind ... [at the time of the homicide]?

A: ... I would say that he was in a state of uncontrollable rage which was a product of having to contend with what seems to me an incredibly provacative [sic] situation, an incredibly provacative [sic] young woman, and that this immediate situation was superimposed upon Mr. Berry having encountered the situation time and time again. So that we have a cumulative effect dating back to the way his mother dealt with him.

...

Q: ... [Y]ou say that the situation involving Rachel Berry and Albert Berry ... was the product of . . . cumulative ... provocations. Now, specifically, what would you base your opinion as to provocations on?

$\cdots$

A: ... We have two factors here. ... The past history, that is, the history of this man well in advance of his meeting the deceased. And then the history of his relationship with her. And I think the two go together .... After 15 years [of marriage to his second wife] and five children, his wife leaves him for ... another man. ... They continued to live together, during which time his wife taunted him about her boyfriend.

One night while they were having sex, his wife [calls him by the name of her boyfriend.] Despondent and enraged at the same time, he went into the kitchen, obtained a knife, and stabbed his wife in the abdomen.

209. Trial Transcript at 145, Berry, No. 88-2b Crim. No. 19194 (describing Berry's destruction of a lover's stereo).

210. The court recounts Blinder's testimony regarding Rachel's provocative behavior and then concludes: "Dr. Blinder testified that as a result of this cumulative series of provocations, defendant ... was in a state of uncontrollable rage, completely under the sway of passion." People v. Berry, 556 P. $2 \mathrm{~d}$ at 780. In dismissing Berry's claim for an instruction on diminished capacity, the court again takes Blinder's description of Berry's cumulative passion out of context: "[Blinder] stated that the time of the killing, defendant was in [a state] . . . of uncontrollable rage [which was] ... ' a product of having to contend with what seems to me an incredibly provocative situation, an incredibly provocative young woman, and that this immediate situation was superimposed upon Mr. Berry having encountered the situation time and time again." Id. at 782 (emphasis added.) The court concludes that this testimony relates to "a course of provocatory conduct on the part of Rachel," $i d$., but fails to mention that the situation that Berry "encountered time and time again" did not refer merely to his experience with Rachel, but encompassed his entire life experience with women.

211. Trial Transcript at 141-45, Berry, No. 88-2b Crim. No. 19194 (emphasis added). 
And she was not serious. He only got to spend a year in jail for that. ${ }^{212}$

So we have this pattern of enormous dependency on these women and then rupture of the relationship with tremendous rage, almost uncontrollable. I think in one instance he put his foot through the stereo ... he had purchased for one of these girls [sic] ....

So we see a succession of women, beginning with his mother, who offer the promise of comfort but ultimately deliver indifference and emotional pain.

The irony of this defense testimony is found in its confirmation that Berry had a propensity to assault wives and lovers under circumstances in which he claimed the woman's infidelity provoked him. Rachel, then, became the recipient of Berry's cumulative rage against all the past women in his life. In a tautological way, Berry's past abuse of other women was used to strengthen his claim of Rachel's provocative nature: Berry had a pattern of involvement with emotionally abusive women; his violence was in response to their "abuse"-never the other way around. Rachel was involved with Berry; therefore, it is more than likely that Rachel emotionally abused Berry and that his violence was the result of provocation occasioned by her abuse. Dr. Blinder makes this leap of logic quite explicit in response to the District Attorney's attempt to probe his knowledge of Rachel's (supposed) subconscious suicidal motivation:

Q: ... [A]ssuming that [Rachel's suicidal] statement was made after the time of ... her first husband's tragic accidental death. Would that have any effect [on your assessment] as to her [suicidal] state of mind? A: . . Not much, Mr. Winkler. Any woman who engaged in a relationship with [Berry] clearly has serious depressive and suicidal impulses. ${ }^{213}$

Again, the District Attorney attempted to highlight Blinder's complete reliance on Berry for his clinical assessment of Rachel and Berry's former lovers:

212. Id. Though the exact nature of the charge is not apparent, it was a felony and Berry was currently on parole for the crime. In Berry's own testimony he says he stabbed his former wife 4 times with a butcher knife. Id. at 253 . The prosecutor intimates that it was actually 11 times with a 15 inch butcher knife. Id. at 155 . Blinder's devaluations of the severity of domestic violence-i.e., "and [her condition] was not serious"-is a bias shared by many mental health professionals as well as among the criminal justice system. See generally Adams, supra note 13 (describing treatment models for men who batter).

213. Trial Transcript at 175, Berry, No. 88-2b Crim. No. 19194 (emphasis added). 
Q: . . Really, everything that you have [about Rachel] basically is what Mr. Berry tells you about her?

A: ... Well, let's put it this way, Mr. Winkler. ... We're looking at a man who's had a series of relationships which have been in the same pattern time after time and which have all ended in much the same way, not perhaps the violent outcome but at least psychologically the same kind of outcome. It would be very surprising if Mr. Berry did any better in this relationship than he did with all the others. ${ }^{214}$

Q: ... You are basing your opinion that [Berry] had these types of relationships primarily on what Mr. Berry tells you, is that correct...? A: . . Well, in part. I think I am basing it primarily on my ability to detect, identify familiar clinical patterns and some of the data that Mr. Berry gives me fits into this clinical pattern .... When you get a total longitudinal history of this man, one can almost draw up the nature of his relationships with women without his telling you a great deal about them. ${ }^{215}$

\section{Obsessive Thinking: Rehearsal for Murder}

Indicia of premeditation of the obsessive, brooding kind characteristic of batterers is clear in Berry. Berry himself said in his police statement, "I deliberately waited to kill her. No pretense, no bullshi[t], no nothing."216 Berry's long wait for Rachel to return home provides further evidence. His two prior assaults on Rachel also suggest premeditation, but the court's failure to understand the escalating, obsessive nature of wife battering prevents its recognition. The opinion relies on Blinder's explanation that the two prior assaults were evidence of Berry's increasingly provoked state. ${ }^{217}$ In fact, prior assaults just as easily support a "rehearsal" model or provide evidence of Berry's resort to increasingly dangerous tactics in order to control Rachel. Berry's ambivalence-his uncertainty about whether or not he intended to kill Rachel-and the fact that his two prior assaults of Rachel were similar in kind though not in severity, strongly point to the kind of "locked-in"- - "it all depends on what she does"-sense of causality that mark the most dangerous of abusive men. ${ }^{218}$ Berry's confession evidences this kind of ambivalence. $\mathrm{He}$ requests to go back on the record to say, "I knew damn well when I was

214. Id. at 167. Research regarding battered women has provided no such psychological typology. See Dutton et al., supra note 208. Though significant commonalities exist between abusive men, no such similarities exist between women subject to a man's abuse.

215. Trial Transcript at 156-57, Berry, No. 88-2b Crim. No. 19194 (emphasis added).

216. Statement of Berry at 16 , No 88-2b Crim. No. 19194.

217. People v. Berry, 556 P.2d at 780 (" $[T]$ he long course of provocatory conduct . . . had resulted in intermittent outbreaks of rage. ...").

218. See supra notes $70-75$ and accompanying text. 
waiting there for her, I'd probably kill her"219 but at trial testified that when Rachel asked if he'd come to kill her, he first said "yes" then "no" then "yes" again.220 While Berry admits that he knew he would "probably kill her," he also states that his intent was to make her stop screaming: "She come in the door. She started screaming. I told her to shut up. All I wanted to do was talk. She kept screaming at me. I grabbed her and we wrestled ... a and I tried to shut her up. She wouldn't stop screaming. I wrapped the phone cord around her [neck]".221

\section{Rachel's Supposed Failure to Exit ${ }^{222}$ and Berry's Defense}

The defense portrayed Rachel as a vindictive-albeit confusedwoman who sexually used and abused Berry in order to gain her own death. The defense strategy was to play on an old theme which surfaces throughout the legal system's treatment of battered women: "If it was so bad, why did she stay?" The defense recognized that the motivations of a woman who is being abused by her partner are nearly universally seen as suspect-or at the least, extremely problematic. ${ }^{223}$ As Martha Mahoney has described, this focus on the woman's perceived failure to leave makes her acts of resistance invisible-resistance which may take the form of "staying" or "leaving" or some of both. ${ }^{224}$ Mahoney notes that failure to exit a battering relationship is used against a woman: either "to dispute the truth of descriptions of physical violence (if it was so bad, why didn't she leave?)" or-as in Rachel's case- "to question her functionality."225 Rachel's attempts to resist Berry's violence-whether through physical self-defense, ${ }^{226}$ contact with and threats to contact his probation

219. Statement of Berry at 23, No. 88-2b Crim. No. 19194.

220. Trial Transcript at 273, Berry, No. 88-2b Crim. No. 19194.

221. Statement of Berry at 3, No. 88-2b Crim. No. 19194.

222. The term is a paraphrase of Martha R. Mahoney, Exit: Power and the Idea of Leaving in Love, Work, and the Confirmation Hearings, 65 S. CAL. L. REv. 1283, 1285 (1992) ("If abuse is asserted, 'failure' to exist must then be explained.").

223. See id. at 1286-89 ("The woman's very presence in the battering relationship is used against her in several ways."). Blinder's testimony gave an answer to the "why does she stay?" question that was satisfying in its completeness and, at the same time, resonated with deeply imbedded masochism stereotypes of battered women: She "stayed" with Berry because she wanted to die. Trial Transcript at 151, Berry, No. 88-2b Crim. No. 19194.

224. Mahoney, supra note 222, at 1300 . Mahoney notes that "the question 'why didn't she leave?' shapes the discourse on battering ... [and] directs attention away from the batterer's quest for power and control, shifting inquiry. to the legitimacy of response in the person who was harmed." Id. (emphasis in original).

225. Id. at 1287.

226. People v. Berry, 556 P.2d at 779 (Rachel scratched Berry "deeply many times" in attempting to defend herself.). 
officer, ${ }^{227}$ separation from Berry, turning to her friends, ${ }^{228}$ or the filing of criminal charges - are made completely invisible by Dr. Blinder's testimony and are disregarded by the California Supreme Court as well. They are hidden by Blinder's assumption that Rachel "stayed"229 with Berry in order to achieve her subconscious desire for her own death. If Rachel desired suicide-even if "subconsciously"-why did she separate from Berry and why did she initiate criminal charges? One is left to wonder just how Rachel could have extricated herself from the situation in a manner that Blinder would have recognized as not complicit with Berry's intent to kill her.

\section{C. "Loss of Control": She Made Me Do It}

The doctrine and the complementary views of battering as a phenomena of "loss of control" surface repeatedly in Blinder's testimony, in Berry's testimony and police statement, and in the opinion of the California Supreme Court. The legal doctrine always, of course, shapes the defense story. It is therefore hardly surprising that while Berry's original statement to the police suggested several possible motives for killing Rachel, ${ }^{230}$ by the time of trial, "jealousy and sexual rage"231 were the sole motivations forwarded by the defense. However, the "out of control" understanding permeates the entire case in far more subtle ways than can be explained by mere defense strategy. The California Supreme Court opinion repeatedly echoes the tenor of Blinder's words-using terms such as "the result" or "culmination"- -terms that diffuse responsibility and make Berry's violence seem inevitable and uncontrollable. For example, the opinion notes that Rachel's provocative behavior "resulted" in Berry's attacks; her confession of her love affair with Yacob "brought about further argument and a brawl that evening [after she returned from

227. Infra note 240 and accompanying text.

228. Rachel told her friends she was afraid of Berry. See Trial Transcript at 347-48, Berry, No. 88-2b Crim. No. 19194 (Direct examination of Mrs. Lichaa, Rachel's former co-worker; Rachel told Mrs. Lichaa, shortly before she was killed, that she was scared that Berry would kill her.).

229. See discussion supra note 201 and accompanying text. Though Blinder's testimony serves to "explain" why Rachel stayed, the fact is she did not stay-Berry returned.

230. See Statement of Berry, at 6, 8-9, 14-15, and 21, Berry, No. 88-2b Crim. No. 19194. Those motivations were (1) to make her stop screaming; (2) to stop her plan to blame Berry for an auto accident which seriously injured a pedestrian and for which she was responsible; (3) revenge for money she had borrowed from Berry and later refused to repay; (4) revenge for the arrest warrant Rachel had initiated; (5) retaliation for her threats to tell Berry's probation officer about the two previous attacks.

231. People v. Berry, 556 P.2d at 780. The California Supreme Court's opinion seems to also imply that Rachel's screaming was another provocative event. Id. at 781 ("[Berry's rage] reached its final culmination in the apartment when Rachel began screaming."). 
Israel] in which defendant choked Rachel and she responded by scratching him deeply many times."232 Rachel's "taunts and incitements" "led defendant to choke her on two occasions, until finally [Rachel] achieved her unconscious desire [for suicide] and was strangled."233 And the court further notes that "[Rachel's] long course of provocatory conduct ... had resulted in intermittent outbreaks of rage ... [which] reached its final culmination in the apartment when Rachel began screaming."234

Time and again the court identifies Rachel as the actor and Berry as the one who is acted upon. The violence "results," a brawl is "brought about" by Rachel's behavior, and Berry is therefore "led" to choke her. ${ }^{235}$ Where Berry's violence is not directly attributed to Rachel, it is described in terms that imply mutuality. For example, an assault in which Berry choked Rachel is described as a "brawl."236 Berry's own words belie this "out of control" focus. He states that Rachel "held [the first assault] over his head."237 He reports that when Rachel threatened to "sign that God damn report" and have his probation officer put him in jail, Berry's response was, "[I]f that's the case you want to put me in jail for something, I might as well do something. So I grabbed her by the throat and she passed out and I quit."238

\section{BERRY's JUSTIFICATION Claims}

\section{The "Bitch Deserved It" Defense}

Blinder's description of Rachel serves to recreate and reinforce the old sexist notions of "bad" women-women who deserve to be hit. To a great extent, the fight between the prosecution and the defense became whether or not Rachel was a "bitch." The prosecution presented testimony that Rachel was "sweet" to rebut Blinder's testimony that she was "a tease." This is most clearly seen in Blinder's testimony regarding Rachel's conversation with Berry's parole officer. Blinder implies that Rachel's threats to tell Berry's parole officer of the second assault, were attempts to manipulate Berry-to abuse him. ${ }^{239}$ On cross-examination of Blinder the prosecution attempts to create a different image of Rachel,

232. Id. at 779 .

233. Id.

234. Berry, 556 P.2d at 781.

235. Id. at 779.

236. Id.

237. Statement of Berry at 9, Berry, No. 88-2b Crim. No. 19194.

238. Id. at 14.

239. Trial Transcript at 161-62, Berry, No. 88-2b Crim. No. 19194. 
but one no less bound by the dichotomy of provocateur/bitch vs. "good"/helpless woman: ${ }^{240}$

Q: And did she in fact not beg [the parole officer] to forgive Albert because she forgave him and she wanted him to give him another chance? ... [Assuming this to be true] would that not tend to mitigate against the kind of picture Mr. Berry attempted to draw to you of Rachel?

A: No. In fact, it just goes along with the classical picture of the very nature of her personality and his personality too. On the one hand, she is begging, "forgive my wonderful husband, I love him, I don't want the Court to find out about this." Yet, of course, she is the principal vehicle by which this information might be funneled to the Court. ... [She says] 'I am only telling you about these things for his own good.' But in the process of pleading for him she potentially slits his throat. ...

Q: Who could a person, a wife turn to, assuming she doesn't have her own private psychiatrist, in a situation of this sort where she was choked into unconsciousness?

A: That depends on whether or not she wants to see her husband be put behind bars.

...

Q: But it is always equally, reasonably probable, is it not, that she went up there to try to get help for this marital state?

The prosecution and defense have created bi-polar extreme definitions of Rachel: either she is the ultimate self-sacrificing woman, going to the probation officer only to get help with her marital state in complete disregard of her own safety, eager to protect Albert from any consequences of his assault on her or, alternatively, she is a manipulative tease whose only interest in talking with the probation officer was to ensure that she had some power over Berry-power she was determined to use to hurt him. It is likely that Rachel wanted some measure of protection and some control over Berry to the extent that he would be less likely to hurt her again, but she did not want to lose control of her relationship entirely to the power of the state. She may have hoped, as many women do, that, with the proper controls, she could safely continue to live with Berry. ${ }^{241}$

240. Id. (emphasis added).

241. This combination of controls is precisely the balance that many women attempt to strike with temporary restraining orders. See Robel, supra note 9 (arguing that temporary restraining orders sometimes have the benefit of providing the abused woman with an increased ability to negotiate with the abuser or provide controls on the abusive behavior). These statements seem to also indicate that a serious minimization of Rachel's fear and danger. This minimization is further evidenced by Blinder's description of an earlier choking attack: "Finally, exhausted, the Defendant 


\section{Berry's Quasi Self-Defense Claim}

In response to the Attorney General's argument that the twenty hours Berry spent waiting in the house for Rachel to return was, as a matter of law, an adequate cooling off period, the court notes: "the long cause of provocatory conduct ... reached its final culmination in the apartment when Rachel began screaming."242 The court, in essence, ruled that Rachel's screaming was the final act that, on the heels of the past provocatory conduct, moved Berry to kill her. The court's acceptance of Rachel's screaming as the final culminating event is completely contrary to an established principle of California voluntary manslaughter doctrine: that is, that the behavior of a resisting victim can never provide adequate provocation to mitigate murder to manslaughter. ${ }^{243}$ No commentary has addressed this contradiction-presumably because the fact that the case was a domestic violence case completely obscures the uncontroverted evidence that Berry entered Rachel's apartment with the supposition-if not the clear intent-that he would hurt her.

Berry, too, considered Rachel's screaming to be provocative. In his statement to the police he suggested that he killed Rachel just to shut her up. ${ }^{244}$ This wasn't the first time Berry portrayed his violence against Rachel as self-defense in response to Rachel's verbal and psychological abuse. Berry testified that the second time he choked Rachel it was in response to a slur on his parenting:

She said, 'I never want to see you again. I never want to talk to you again. I hate you. You don't even care for your own children. You never do anything for your own children, try to get in touch with them. How do you expect me to think that you care for me? ${ }^{245}$

asked his wife to please shut up so he could get some sleep.... She continues. Finally, he grabs her around the neck and chokes her until she almost faints. The next ten days are characterized by bitter fights over his purported possessiveness and abuse of her." Trial Transcript at 147, Berry, No. 88-2b Crim. No. 19194 (emphasis added).

242. People v. Berry, 556 P.2d at 781.

243. See supra note 130 and accompanying text (predictable conduct of a resisting victim cannot provide adequate provocation to mitigate a crime of murder to manslaughter). See, e.g., People v. Johnson, 146 Cal. Rptr. 476 (Ct. App. 1978) ("Berry killed his wife with the telephone cord in an attempt to keep her from screaming.") (emphasis added).

244. Statement of Berry at 14, Berry, No. 88-2b Crim. No. 19194 ("[Rachel] walked in and started screaming, and I grabbed her and I said, shut up.... And she wouldn't stop screaming, and I got scared."). Id. at 21 ("[Rachel] comes in, she sees me, she starts screaming .... And she didn't stop screaming. She said the police are outside, and I said, I don't care if the police are out there or not. I said all I want to do is talk to you. And then she grabbed me and started biting, trying to bite. So I threw her down on the floor and I grabbed the cord. I said, now you'll shut the hell up, won't you."). If indeed Rachel's screaming played a role in Berry's decision to kill her, it may very well be because he feared arrest.

245. Trial Transcript at 268, Berry, No. 88-2b Crim. No. 19194. 
Of course, Berry's trial testimony largely matched Blinder's testimonyboth portraying Berry as a chronic victim of women: Berry's violence was merely in response to such tormenting behavior. ${ }^{246}$ However, Berry's police statement-given before he'd talked to his attorney-may provide a more accurate assessment of how Berry actually saw Rachel. As noted earlier, the most significant difference between the statement and Berry's testimony-other than his retraction of statements indicating premeditation, claiming they were self-destructive lies ${ }^{247}$-was that the number of "reasons" Berry gave for the killing had narrowed dramatically to two: sexual jealousy and rage. ${ }^{248}$ His statement is otherwise consistent-if not in specifics, certainly in emotional tone-to his subsequent testimony. Berry portrayed himself, and likely believed himself to be, the real victim. When asked by the police why he didn't just leave Rachel"[w]hat made you want to take her life first?"249-Berry responded,

I had so much planned in the future, everything. We were going to open up a restaurant when she came back [from Israel]. Had it all planned we were going to move, we were going to get out of that apartment because of bad memories .... I never denied her anything. She could have anything-as a matter of fact, when she was in Israel I sent her my last God damn hundred dollars. ${ }^{250}$

This testimony portrays a man who is feeling great disappointment and loss. It also portrays a man wholly captured by his own perspective of reality-unable to imagine what was motivating Rachel. Berry's pain, no doubt, was genuine, but it was not his pain that killed Rachel. Berry was able to present himself--to himself-as the cuckold, the man wronged by a spendthrift, golddigger wife several years his junior. ${ }^{251}$

246. See supra note 205 and accompanying text (describing Blinder's testimony characterizing Berry as chronically abused by women); see Trial Transcript at 242-43, Berry, No. 88-2b Crim. No. 19194 (Berry describing the unfaithfulness of his first wife), at 245-46 (describing his mother's rejection of him as an adult), at 248-49 (describing himself as "feeling useless" with his second wife because she "had completely taken over"), at 252-53 (explaining his stabbing of his second wife as the result of her involvement with another man), at 254 (girlfriend he met after second divorce locks him out of the house simply because "[they] just didn't get along"), at 256 (describing his assault on Rachel Pessah, allegedly because of her involvement with Yacob), and at 268 (describing second assault on Rachel allegedly in response to her refusal to "let" him leave and because she stated that he didn't care about his children.).

247. Berry testified that much of the statement was not true because his state of mind was selfdestructive and he was intent on "putting ... premeditating murder one on [himself]." Berry Trial Transcript at 276, Berry, No. 88-2b Crim. No. 19194.

248. See supra note 231 and accompanying text.

249. Statement of Berry at 18, Berry, No. 88-2b Crim. No. 19194.

250. Id.

251. Berry's explanation for why he killed Rachel instead of just divorcing her, plays heavily on themes of victimization: "I had so much planned in the future, everything. We were going to open 
These cultural stereotypes facilitated Berry's belief in himself as "victim."

Though Blinder's testimony focused on Rachel's "provocative" sexual behavior, the truth is that Berry didn't kill Rachel until it appeared that she might make good on her threat to leave him. ${ }^{252}$ As discussed earlier in this article, Blinder's testimony completely ignores this fact. Not surprisingly, perhaps, Blinder's testimony is completely from Berry's perspective: the relationship dynamics continue, even though Rachel has rejected attempts at reconciliation and has filed a police report. Of course, a defense witness tells it from the perspective of the accused, but in this circumstance, the defendant's perspective is largely that of the Court and that of the Law, as well. That perspective, as identified in this article, suggests that a woman's "abandonment" of a husband is provocative-and that a woman's preference of another lover is provocation of the worst sort.

\section{CONCLUSION}

The understanding of heat of passion homicides currently overlaps with traditional understandings of wife killings. This overlap operates in two mutually reinforcing directions. First, to a large extent heat of passion killings are defined as domestic violence killings. This can be seen in the doctrinal status of adultery as the paradigm heat of passion case, in the popular as well as clinical descriptions of domestic violence as the result of "passion" and "provocation," and in criminal law's unusual emphasis on the mental life of the man who kills an intimate. ${ }^{253}$ Second, are the significant ways in which the excuses and justifications given by abusive men match elements of and assumptions that underpin voluntary manslaughter doctrine. The central excuse of battering men-that their violence results from being out of control-resonates with and is reinforced by the legal doctrine. The instrumental nature of domestic violence is thus made invisible: the batterer's ongoing struggle for control of

up a restaurant when she came back. Had it all planned we were going to move, we were going to get out of that apartment because of bad memories .... I never denied her anything. She could have anything - as a matter of fact, when she was in Israel I sent her my last God damn hundred dollars." Statement of Berry at 18, Berry, No. 88-2b Crim. No. 19194.

252. See Mahoney, supra note 2, at 74 (describing Berry as a case of "separation assault").

253. See Rapaport, supra note 191, at 26:

Excessive psychologizing and individualized consideration of the suffering of denied domestic killers tends to allow men to retain by force and threat of force that which the equality of the sexes and the reform of marriage was designed to remove: their right to control the women in their lives.... [Those who commit "predatory" murders] also have emotional lives; but the criminal law has been more resistant to folding the emotional life of predators into sentencing considerations than it has in the case of domestic crime. 
the woman is lost in the story of his inability to control himself. Further, this belief in the "uncontrollability" of the killer's violence suggests that the violence cannot be deterred. Both domestic violence and "heat of passion" killings are viewed-independently-to be crimes unlikely to respond to deterrence measures. The cultural overlap between the two categories of crime further reinforces this belief and prevents the recognition that studies showing that aggressive police intervention decrease spousal homicide rates, ${ }^{254}$ presents a serious challenge to the "out of control" assumption. Similarly, when abusive men justify their violence in terms that portray themselves as emotional victims and their violence as necessary self-protection, their justification resonates with comparable underpinnings of voluntary manslaughter doctrine. The story of male victimhood may be couched in sophisticated psychological language utilizing a "systems" or "interactionist" approach, such as the psychiatric testimony of Blinder in Berry, or it may instead rest baldly on the assumption that a wife's sexual unfaithfulness or verbal assertiveness is the equivalent of a physical assault which demands a physical response.

The modern analysis of wife-beating belongs in today's legal analysis of wife-murder. It is somewhat ironic that while traditional social understandings of wife-killings overlap with those of heat of passion doctrine, the modern analysis of wife-battering is entirely missing in today's legal analysis of wife-killings. This analysis centers on the importance of the abuser's attempt to control the woman and the particularly dangerous manifestation of this control in response to her attempts to separate. The absence of this analysis to wife-killings evidences a de facto legal and cultural separation between wife-battering and wife-murder. If we eliminate that separation, we eliminate two dangerous myths: first, that men who kill their wives or girlfriends do so in the heat of "uncontrolled passion"; second, that men who kill are not likely to kill again. The first myth results in a failure to recognize that while wife-killings marked by brooding, obsessive behavior may not match a "predatory,"255 "rational" conception of premeditated murder, they are nevertheless planned killings. The second myth results in the failure to recognize the relevance of the insurmountable evidence that men who batter do so in relationship after relationship, negating the theory that recidivism in the wife-murder context is unlikely.

254. See supra note 79 and accompanying text; supra note 138 and accompanying text.

255. See Rapaport, supra note 191 (with "predatory" crimes the emotional life of the accused is not so thoroughly examined). 
To provide the protection for abused women that the criminal justice system and this society should provide, we must recognize the culturally reinforcing nature of the overlap between how abusive men think and how the legal doctrine works. We must eliminate the de facto legal and cultural separation between wife-beaters and wife-killers, placing the legal and cultural analysis of wife-murder squarely within that of wifebattering. 